\title{
A new species of Leptobrachella (Anura, Megophryidae) from Guizhou Province, China
}

\author{
Tao Luo ${ }^{* *}$, Ning Xiao ${ }^{2 *}$, Kai Gao ${ }^{3}$, Jiang Zhou' \\ I State Engineering Tecenology Instiute For Karst Desertification Control School of Karst Science, Guizhou \\ Normal University, Guiyang 550001, Guizhou, China 2 Guiyang Nursing Vocational College, Guiyang, \\ Guizhou, 550003, China 3 Ministry of Education Key Laboratory for Biodiversity and Ecological Engineering, \\ College of Life Sciences, Beijing Normal University, Beijing 100875, China
}

Corresponding author: Jiang Zhou (zhoujiang@ioz.ac.cn)

Academic editor: Angelica Crottini | Received 9 October 2019 | Accepted 15 February 2020 | Published 1 April 2020

http://zoobank.org/104B0C71-0826-4C50-938B-FD78C4D403A6

Citation: Luo T, Xiao N, Gao K, Zhou J (2020) A new species of Leptobrachella (Anura, Megophryidae) from Guizhou Province, China. ZooKeys 923: 115-140. https://doi.org/10.3897/zookeys.923.47172

\begin{abstract}
This study describes a new species of the genus Leptobrachella, Leptobrachella suiyangensis sp. nov. from the Huoqiuba Nature Reserve, Suiyang County, Guizhou Province, China, based on morphological data and phylogenetic analyses (16S rRNA mtDNA). The new species can be distinguished from other congeners by the molecular divergence and by a combination of morphological characters, including body size, dorsal and ventral patterns, dorsal skin texture, size of the pectoral and femoral glands, degree of webbing and fringing on the toes and fingers, dorsum coloration, and iris coloration in life. Currently, the genus Leptobrachella contains 75 species, 21 of which are found in China, including seven species reported from Guizhou Province. The uncorrected sequence divergence percentage between Leptobrachella suiyangensis sp. nov. and all homologous DNA sequences available for the $16 \mathrm{~S}$ rRNA gene was found to be $>4.7 \%$. The new record of the species and its relationships with others in the same genus imply that species distribution, habitat variation, environmental adaptation, and diversity of the genus Leptobrachella in southwest China need to be further investigated.
\end{abstract}

* These authors contributed equally to this paper

Copyright Tao Luo et al. This is an open access article distributed under the terms of the Creative Commons Attribution License (CC BY 4.0), which permits unrestricted use, distribution, and reproduction in any medium, provided the original author and source are credited. 


\section{Keywords}

Leptobrachella suiyangensis sp. nov., mitochondrial DNA, morphology, Southwest China

\section{Introduction}

The genus Leptolalax Dubois, 1983 in the family Megophryidae Bonaparte, 1850 is regarded to be closely associated with the genus Leptobrachella Smith, 1925 and has been assigned as a synonym of the genus Leptobrachella based on a large-scale molecular analysis (Chen et al. 2018). The genus Leptobrachella is now considered to contain 74 species. The genus is widely distributed from southwestern China to northeastern India and Myanmar (Fei et al. 2012; Frost 2019), extending to mainland Indochina, peninsular Malaysia, and the islands of Borneo (Rowley et al. 2016, 2017a; Yang et al. 2016; Yuan et al. 2017; Wang et al. 2018; Nguyen et al. 2018). Currently, 20 species of this genus are known from China. They are: Leptobrachella alpina (Fei, Ye \& Li, 1990) and L. bourreti (Dubois, 1983) from Yunnan and Guangxi; L. eos (Ohler, Wollenberg, Grosjean, Hendrix, Vences, Ziegler \& Dubois, 2011) and L. nyx (Ohler, Wollenberg, Grosjean, Hendrix, Vences, Ziegler \& Dubois, 2011) from Yunnan; L. laui (Sung, Yang \& Wang, 2014) and L. yunkaiensis Wang, Li, Lyu \& Wang, 2018 from southern Guangdong, including Hong Kong; L. liui (Fei \& Ye, 1990) from Fujian, Jiangxi, Guangdong, Guangxi, Hunan, and Guizhou; L. oshanensis (Liu, 1950) from Gansu, Sichuan, Chongqing, Guizhou, and Hubei; L. purpuraventra Wang, Li, Li, Chen \& Wang, 2019 and L. bijie Wang, Li, Li, Chen \& Wang, 2019 from Guizhou; L. purpurus (Yang, Zeng \& Wang, 2018), L. pelodytoides (Boulenger, 1893), L. tengchongensis (Yang, Wang, Chen \& Rao, 2016) and L. yingjiangensis (Yang, Zeng \& Wang, 2018) from Yunnan; L. ventripunctata (Fei, Ye \& Li, 1990) from Guizhou and Yunnan; $L$. mangshanensis (Hou, Zhang, Hu, Li, Shi, Chen, Mo \& Wang, 2018) from southern Hunan, and L. sungi (Lathrop, Murphy, Orlov \& Ho, 1998), L. maoershanensis (Yuan, Sun, Chen, Rowley \& Che, 2017), L. shangsiensis Chen, Liao, Zhou \& Mo, 2019, and L. wuhuangmontis Wang, Yang \& Wang, 2018 from Guangxi (Sung et al. 2014; Yang et al. 2016, 2018; Yuan et al. 2017; Wang et al. 2018, 2019; Hou et al. 2018; Chen et al. 2018, 2019; Wang et al. 2019; AmphibiaChina 2019).

During a field survey in June 2018 in a montane evergreen forest, Suiyang County, Guizhou Province (Fig. 1), we collected three different species of the family Megophryidae co-occurring in this small-fragmented forest. The specimens could be morphologically separated from one another. Subsequent studies based on morphological and molecular data indicated that two of the three could be classified as Megophrys minor Stejneger and M. spinata Liu and $\mathrm{Hu}$, while the third population, differing significantly from the other two, was further analyzed via morphological characters. Subsequent $16 S$ rRNA sequences from these specimens revealed that the collection represented distinct evolving lineages and belong to the genus Lepobrachella. Combining morphological characters, acoustic data, and molecular divergence, we described the specimens as a new species. 


\section{Materials and methods}

\section{Sampling}

Eight specimens collected from the aforementioned area (Fig. 1) were euthanized with chlorobutanol solution and fixed in 10\% formalin for $24 \mathrm{~h}$, and then stored in $75 \%$ ethanol. Liver and muscular tissues were taken before fixing and preserved in $95 \%$ alcohol at $-20^{\circ} \mathrm{C}$. All of the specimens are kept at the College of Life Sciences, Guizhou Normal University (GZNU), Guiyang City, Guizhou Province, China.

\section{DNA Extraction, PCR and sequencing}

DNA samples were extracted from muscular tissues with a DNA extraction kit (Tiangen Biotech (Beijing) Co. Ltd). The mitochondrial gene and 16S ribosomal RNA gene (16S rRNA) were sequenced (951bp). The fragmented genes were amplified with primer pairs L3975 (5'-CGCCTGTTTACCAAAAACAT-3') and H4551 (5'-CCGGTCTGAACTCAGATCACGT-3') for 16S rRNA (Simon et al. 1994). PCR amplifications were performed in a $20 \mu \mathrm{l}$ reaction volume with the following cycling conditions: an initial denaturing step at $95^{\circ} \mathrm{C}$ for five min; 35 cycles of denaturing at $95^{\circ} \mathrm{C}$ for $40 \mathrm{~s}$, annealing at $53^{\circ} \mathrm{C}$ for $40 \mathrm{~s}$ and extending at $72^{\circ} \mathrm{C}$ for $1 \mathrm{~min}$, followed by a final extending

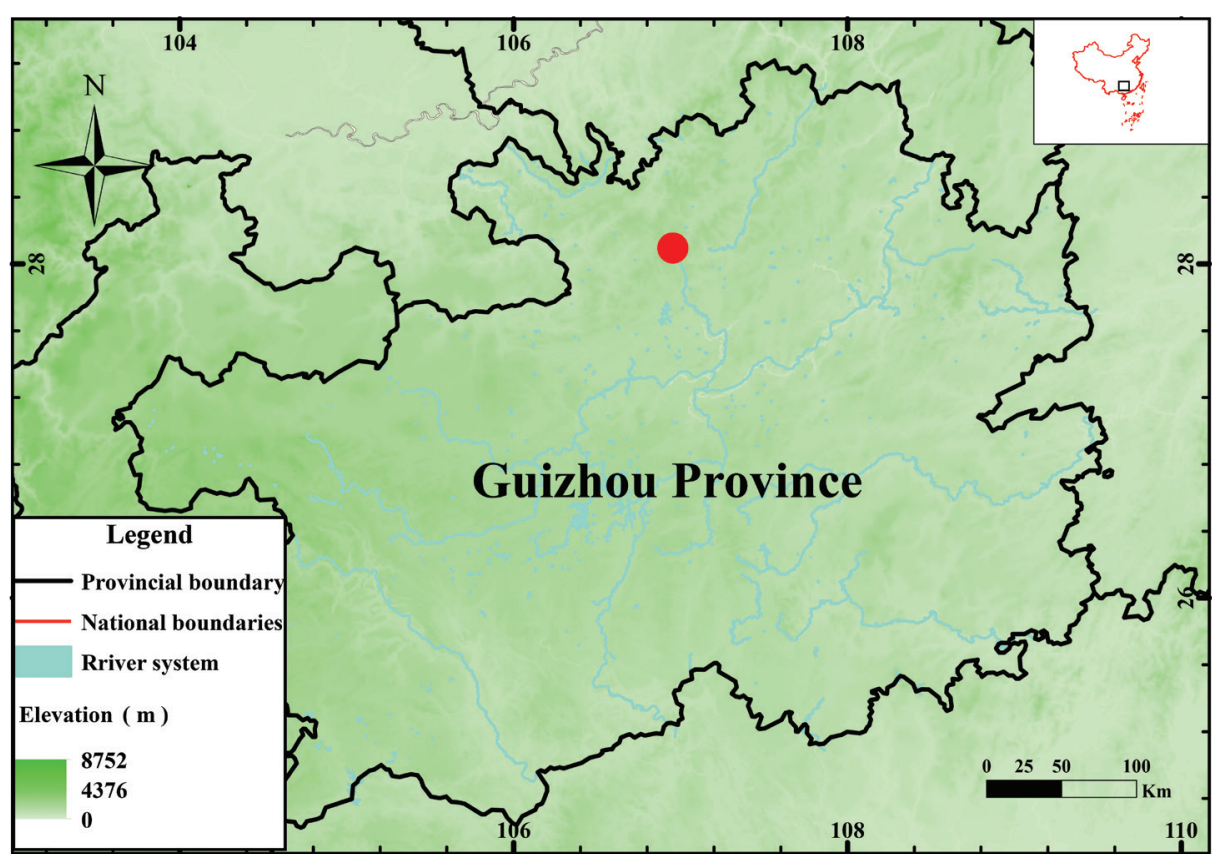

Figure I. Collection locality (red circle) of Leptobrachella suiyangensis sp. nov. from Suiyang County, Guizhou province, China used in this study. 
step of $72{ }^{\circ} \mathrm{C}$ for $10 \mathrm{~min}$. PCR products were purified with spin columns. The purified products were sequenced with both forward and reverse primers using a BigDye Terminator Cycle Sequencing Kit according to the guidelines of the manufacturer. The products were sequenced on an ABI Prism 3730 automated DNA sequencer at Shanghai Majorbio Bio-pharm Technology Co. Ltd. All sequences have been deposited in GenBank (Table 1). For molecular analyses, a total of 77 sequences $(74$ sequences downloaded from GenBank and three our new sequences) from 55 species of the genus Leptobrachella were used, including one undescribed species from $\mathrm{C}$ hina, that is, the populations from Huoqiuba Nature Reserve, Suiyang County, and Guizhou Province. Three species which sequences downloaded from GenBank are used as outgroups (Leptobrachium huashen Fei \& Ye, 2005, Leptobrachium cf. chapaense (Bourret, 1937) and Megophrys major Boulenger, 1908 (Chen et al. 2018; Wang et al. 2019; Table 1).

Table I. Localities and voucher data for all specimens used in this study.

\begin{tabular}{|c|c|c|c|c|}
\hline ID & Species & Locality & Voucher no. & GenBank no. \\
\hline 1 & Leptobrachella suiyangensis sp.nov. & Suiyang County, Guizhou, China & GZNU20180606002 & MK829648 \\
\hline 2 & Leptobrachella suiyangensis sp.nov. & Suiyang County, Guizhou, China & GZNU20180606005 & MK829649 \\
\hline 3 & Leptobrachella suiyangensis sp.nov. & Suiyang County, Guizhou, China & GZNU20180606006 & MK829650 \\
\hline 4 & Leptobrachella aerea & Vilabuly, Savannakhet, Laos & NCSM 76038 & MH055809 \\
\hline 5 & Leptobrachella aerea & Phong Nha-Ke Bang, Quang Binh, Vietnam & RH60165 & JN848437 \\
\hline 6 & Leptobrachella alpina & Huangcaoling, Yunnan, China & KIZ046816 & MH055866 \\
\hline 7 & Leptobrachella applebyi & $\begin{array}{c}\text { Song Thanh Nature Reserve, Quang Nam, } \\
\text { Vietnam }\end{array}$ & AMS R171704 & HM133598 \\
\hline 8 & Leptobrachella baluensis & Tambunan, Sabah, Borneo, Malaysia & SP 21604 & LC056792 \\
\hline 9 & Leptobrachella bidoupensis & Bidoup, Lam Dong, Vietnam & NCSM 77321 & HQ902883 \\
\hline 10 & Leptobrachella bijie & $\begin{array}{c}\text { Zhaozishan Nature Reserve, Bijie City, } \\
\text { Guizhou, China }\end{array}$ & SYS a007313/CIB110002 & MK414532 \\
\hline 11 & Leptobrachella bijie & $\begin{array}{c}\text { Zhaozishan Nature Reserve, Bijie City, } \\
\text { Guizhou, China }\end{array}$ & SYS a007314 & MK414533 \\
\hline 12 & Leptobrachella botsfordi & Fansipan, Lao Cai, Vietnam & AMS R 176540 & MH055952 \\
\hline 13 & Leptobrachella bourreti & Sapa, Lao Cai, Vietnam & 1999.566 & KR827860 \\
\hline 14 & Leptobrachella brevicrus & $\begin{array}{c}\text { Gunung Mulu National Park, Sarawak, } \\
\text { Malaysia }\end{array}$ & UNIMAS 8957 & KJ831303 \\
\hline 15 & Leptobrachella dringi & Gunung Mulu, Malaysia & KUHE: 55610 & $\mathrm{AB} 847553$ \\
\hline 16 & Leptobrachella eos & Boun Tay, Phongsaly, Laos & NCSM 80551 & MH055887 \\
\hline 17 & Leptobrachella eos & Zhushihe, Yunnan, China & SYS a003959 & MH055888 \\
\hline 18 & Leptobrachella firthi & $\begin{array}{c}\text { Ngoc Linh Nature Reserve, Kon Tum, } \\
\text { Vietnam }\end{array}$ & AMS: R 176506 & JQ739207 \\
\hline 19 & Leptobrachella fritinniens & Gunung Mulu, Malaysia & KUHE55371 & AB847557 \\
\hline 20 & Leptobrachella gracilis & Gunung Mulu, Malaysia & KUHE55624 & $\mathrm{AB} 847560$ \\
\hline 21 & Leptobrachella hamidi & Bukit Lanjan, Selangor, Malaysia & KUHE17545 & AB969286 \\
\hline 22 & Leptobrachella heteropus & Larut, Perak, Malaysia & KUHE15487 & AB530453 \\
\hline 23 & Leptobrachella isos & Gia Lai, Vietnam & AMS R 176469 & KT824767 \\
\hline 24 & Leptobrachella itiokai & Mulu NP, Sarawak, Borneo, Malaysia & KUHE 55845 & LC137802 \\
\hline 25 & Leptobrachella juliandringi & Mulu NP, Sarawak, Borneo, Malaysia & KUHE 55333 & LC056780 \\
\hline 26 & Leptobrachella kajangensis & Tioman, Malaysia & LSUHC 4431 & LC202001 \\
\hline 27 & Leptobrachella kecil & Cameron, Malaysia & KUHE 52440 & LC202004 \\
\hline 28 & Leptobrachella khasiorum & Khasi Hills, Meghalaya, India & SDBDU 2009.329 & KY022303 \\
\hline 29 & Leptobrachella liui & Wuyi Shan, Fujian, China & SYS a001597 & KM014547 \\
\hline 30 & Leptobrachella liui & Wuyi Shan, Fujian, China & ZYCA907 & MH055908 \\
\hline 31 & Leptobrachella laui & Shenzhen, Guangdong, China & SYS a002450 & MH055904 \\
\hline 32 & Leptobrachella laui & Shenzhen, Guangdong, China & SYS a001515 & KM014545 \\
\hline
\end{tabular}




\begin{tabular}{|c|c|c|c|c|}
\hline ID & Species & Locality & Voucher no. & GenBank no. \\
\hline 33 & Leptobrachella macrops & Phu Yen, Vietnam & ZMMU-A5823 & MG787993 \\
\hline 34 & Leptobrachella mangshanensis & Mangshan, Hunan, China & MSZTC201701 & MG132196 \\
\hline 35 & Leptobrachella mangshanensis & Mangshan, Hunan, China & MSZTC201702 & MG132197 \\
\hline 36 & Leptobrachella maoershanensis & Mao'er Shan, Guangxi, China & KIZ07614 & MH055927 \\
\hline 37 & Leptobrachella maoershanensis & Mao'er Shan, Guangxi, China & KIZ027236 & MH055928 \\
\hline 38 & Leptobrachella marmorata & Borneo, Malaysia & KUHE53227 & AB969289 \\
\hline 39 & Leptobrachella maura & Borneo, Malaysia & SP21450 & AB847559 \\
\hline 40 & Leptobrachella melanoleucus & Surat Thani, Thailand & KUHE:23845 & LC201999 \\
\hline 41 & Leptobrachella melica & Cambodia, Ratanakiri & MVZ258198 & HM133600 \\
\hline 42 & Leptobrachella minimus & Doi Chiang Dao, Chiangmai, Thailand & THNHM07418 & JN848402 \\
\hline 43 & Leptobrachella minimus & Doi Suthep, Thailand & KUHE:19201 & LC201981 \\
\hline 44 & Leptobrachella mjobergi & Gading NP, Sarawak, Borneo, Malaysia & KUHE:47872 & LC056787 \\
\hline 45 & Leptobrachella nahangensis & $\begin{array}{c}\text { Na Hang Nature Reserve, Tuyen Quang, } \\
\text { Vietnam }\end{array}$ & ROM 7035 & MH055853 \\
\hline 46 & Leptobrachella nahangensis & Na Hang, Tuyen Quang, Vietnam & ZMMU-NAP-02259 & MH055854 \\
\hline 47 & Leptobrachella nyx & Ha Giang, Vietnam & ROM 36692 & MH055816 \\
\hline 48 & Leptobrachella oshanensis & Emei Shan, Sichuan, China & KIZ025776 & MH055895 \\
\hline 49 & Leptobrachella oshanensis & Emei Shan, Sichuan, China & Tissue ID: YPX37492 & MH055896 \\
\hline 50 & Leptobrachella pallida & Vietnam: Lam Dong & UNS00511 & KU530190 \\
\hline 51 & Leptobrachella parva & Mulu National Park, Sarawak, Malaysia & KUHE:55308 & LC056791 \\
\hline 52 & Leptobrachella petrops & $\begin{array}{c}\text { Cham Chu Nature Reserve, Tuyen Quang, } \\
\text { Vietnam }\end{array}$ & VNMN:2016 A.06 & KY459998 \\
\hline 53 & Leptobrachella picta & Borneo, Malaysia & UNIMAS 8705 & KJ831295 \\
\hline 54 & Leptobrachella pluvialis & Fansipan, Lao Cai, Vietnam & ROM 30685 & MH055843 \\
\hline 55 & Leptobrachella pluvialis & Sapa, Lao Cai, Vietnam & ZMMU-A-5222-02262 & MH055844 \\
\hline 56 & Leptobrachella puhoatensis & Pu Hu, Thanh Hoa, Vietnam & VNMN:2016 A.23 & KY849587 \\
\hline 57 & Leptobrachella purpura & Yingjiang, Yunnan Province, China & SYS a006530 & MG520354 \\
\hline 58 & Leptobrachella purpura & Yingjiang, Yunnan Province, China & SYS a006531 & MG520355 \\
\hline 59 & Leptobrachella purpuraventra & $\begin{array}{c}\text { Wujing Nature Reserve, Bijie City, Guizhou, } \\
\text { China }\end{array}$ & SYS a007081 & MK414517 \\
\hline 60 & Leptobrachella purpuraventra & $\begin{array}{c}\text { Wujing Nature Reserve, Bijie City, Guizhou, } \\
\text { China }\end{array}$ & SYS a007277/CIB110003 & MK414518 \\
\hline 61 & Leptobrachella pyrrhops & Lam Dong, Vietnam & ZMMU A-5208 & KP017575 \\
\hline 62 & Leptobrachella sabahmontana & Borneo, Malaysia & BORNEENSIS 12632 & AB847551 \\
\hline 63 & Leptobrachella shangsiensis & Guangxi, China & NHMG1401032 & MK095460 \\
\hline 64 & Leptobrachella shangsiensis & Guangxi, China & NHMG1401033 & MK095461 \\
\hline 65 & Leptobrachella solus & Hala-Bala, Thailand & KUHE:23261 & LC202007 \\
\hline 66 & Leptobrachella solus & Tam Dao, Vinh Phuc, Vietnam & ROM 20236 & MH055858 \\
\hline 67 & Leptobrachella tengchongensis & Gaoligong Shan, Yunnan, China & SYS a004598 & KU589209 \\
\hline 68 & Leptobrachella tengchongensis & Gaoligong Shan, Yunnan, China & SYS a003766 & MH055897 \\
\hline 69 & Leptobrachella ventripunctatus & Zhushihe, Yunnan, China & SYS a004536 & MH055831 \\
\hline 70 & Leptobrachella wuhuangmontis & $\begin{array}{c}\text { Mt. Wuhuang, Pubei County, Guangxi, } \\
\text { China }\end{array}$ & SYS a003485 & MH605577 \\
\hline 71 & Leptobrachella wuhuangmontis & $\begin{array}{l}\text { Mt. Wuhuang, Pubei County, Guangxi, } \\
\text { China }\end{array}$ & SYS a003486 & MH605578 \\
\hline 72 & Leptobrachella yingjiangensis & Yingjiang, Yunnan, China & SYS a006533 & MG520350 \\
\hline 73 & Leptobrachella yingjiangensis & Yingjiang, Yunnan, China & SYS a006532 & MG520351 \\
\hline 74 & Leptobrachella yunkaiensis & $\begin{array}{l}\text { Dawuling Forest Station, Maoming City, } \\
\text { Guangdong, China }\end{array}$ & SYS a004663 & MH605584 \\
\hline 75 & Leptobrachella yunkaiensis & $\begin{array}{l}\text { Dawuling Forest Station, Maoming City, } \\
\text { Guangdong, China }\end{array}$ & $\begin{array}{l}\text { SYS a004664 / } \\
\text { CIB107272 }\end{array}$ & MH605585 \\
\hline 76 & Leptobrachella zhangyapingi & Chiang Mai, Thailand & KIZ07258 & MH055864 \\
\hline 77 & Leptobrachella zhangyapingi & $\begin{array}{l}\text { Pang Num Poo, Chiang Mai } \\
\text { Province,Thailand }\end{array}$ & JK-2013 & JX069979 \\
\hline 78 & Leptobrachium huashen & Yunnan, China & KIZ049025 & KX811931 \\
\hline 79 & Leptobrachium cf. chapaense & Sapa, Lao Cai, Vietnam & AMS R 171623 & KR018126 \\
\hline 80 & Megophrys major & Kon Tum, Vietnam & AMS R 173870 & KY476333 \\
\hline
\end{tabular}




\section{Phylogenetic analyses}

All sequences were aligned by MUSCLE v. 3.6 with the default settings (Edgar 2004). Trimming with the gaps partially deleted was performed in MEGA 7.0 (Kumar et al. 2016), while within high variable regions, all gaps were removed.

Phylogenetic trees were constructed with both Maximum Likelihood (ML) and Bayesian Inference (BI). The ML was conducted in IQ-TREE (Nguyen et al. 2015) with 2000 ultrafast bootstrapping (Hoang et al. 2018) and was performed until a correlation coefficient of at least 0.99 was reached. The BI was performed in MrBayes v. 3.2.1 (Ronquist et al. 2012), and the best-fit model was obtained by the Akaike Information Criterion (AIC) computed with PartitionFinder 2 (Lanfear et al. 2016), resulting in the best-fitting nucleotide substitution models of GTR + I + G with for BI and ML analysis. Two independent processes were conducted for 10 million generations, sampling every 1000, with four independent chains and a burn-in of $25 \%$. Convergence was assessed referring to the criteria of all parameters having reached stationarity and having obtained satisfactory effective sample sizes (>200) using Tracer v. 1.6. (Rambaut et al. 2014). Nodes in the trees were considered well supported when Bayesian posterior probabilities (BPP) were $\geq 0.95$ and ML ultrafast bootstrap values (UFB) was $\geq 95 \%$ (Chen et al. 2018; Hoang et al. 2018). Uncorrected p-distances based on 16S rRNA were calculated in MEGA v. 7.0 (Kumar et al. 2016).

\section{Morphological and morphometric analyses}

Morphometric data were taken from eight of most well-preserved adult specimens. Measurements were recorded to the nearest $0.1 \mathrm{~mm}$ (Watters et al. 2016) with digital calipers following the methods of Fei et al. (2009) and Rowley et al. (2013). These measurements were as follows:

SVL snout-vent length (from tip of snout to vent)

HDL head length (from tip of snout to rear of jaws)

HDW head width (head width at commissure of jaws)

SNT snout length (from tip of snout to the anterior corner of the eye)

EYE eye diameter (diameter of the exposed portion of the eyeballs)

IOD interorbital distance (minimum distance between upper eyelids)

IND internasal distance (distance between nares)

UEW upper eyelid width (measured as the greatest width of the upper eyelid)

NEL nostril-eyelid length (distance from nostril to eyelid)

NSL nostril-snout length (distance from nostril to snout)

TMP tympanum diameter (horizontal diameter of tympanum)

TEY tympanum-eye distance (distance from anterior edge of tympanum to posterior corner of eye)

TIB tibia length (distance from knee to heel)

ML manus length (distance from tip of third digit to proximal edge of inner palmar tubercle) 
LAHL length of the lower arm and hand (distance from tip of the third finger to elbow)

HLL hindlimb length (distance from tip of fourth toe to vent)

FOT foot length (from proximal edge of the inner metatarsal tubercle to the tip of the fourth toe)

Sex was determined by direct observation of calls in life, the presence of internal vocal sac openings, and the presence of eggs in the abdomen through external inspection. Comparative morphological data of Leptobrachella species were obtained from the references listed in Table 2. Due to the high likelihood of undiagnosed diversity within the genus (Rowley et al. 2016; Yang et al. 2016), where available, we relied on examination of topotypic material and/or original species descriptions.

Table 2. Obtained references of 74 known congeners of the genus Leptobrachella, respectively.

\begin{tabular}{|c|c|c|}
\hline ID & Leptobrachella species & Literature obtained \\
\hline 1 & L. aerea (Rowley, Stuart, Richards, Phimmachak \& Sivongxay, 2010) & Rowley et al. 2010c \\
\hline 2 & L. alpina (Fei, Ye \& Li, 1990) & Fei et al. 2009 \\
\hline 3 & L. applebyi (Rowley \& Cao, 2009) & Rowley and Cao 2009 \\
\hline 4 & L. arayai (Matsui, 1997) & Matsui 1997 \\
\hline 5 & L. ardens (Rowley, Tran, Le, Dau, Peloso, Nguyen, Hoang, Nguyen \& Ziegler, 2016) & Rowley et al. 2016 \\
\hline 6 & L. baluensis Smith, 1931 & Dring 1983; Eto et al. 2016 \\
\hline 7 & L. bidoupensis (Rowley, Le, Tran \& Hoang, 2011) & Rowley et al. 2011 \\
\hline 8 & L. bijie Wang, Li, Li, Chen \& Wang, 2019 & Wang et al. 2019 \\
\hline 9 & L. bondangensis Eto, Matsui, Hamidy, Munir \& Iskandar, 2018 & Eto et al. 2018 \\
\hline 10 & L. botsfordi (Rowley, Dau \& Nguyen, 2013) & Rowley et al. 2013 \\
\hline 11 & L. bourreti (Dubois, 1983) & Ohler et al. 2011 \\
\hline 12 & L. brevicrus Dring, 1983 & Dring 1983; Eto et al. 2015 \\
\hline 13 & L. crocea (Rowley, Hoang, Le, Dau \& Cao, 2010) & Rowley et al. 2010a \\
\hline 14 & L. dringi (Dubois, 1987) & $\begin{array}{c}\text { Inger et al. 1995; Matsui and } \\
\text { Dehling } 2012\end{array}$ \\
\hline 15 & L. eos (Ohler, Wollenberg, Grosjean, Hendrix, Vences, Ziegler \& Dubois, 2011) & Ohler et al. 2011 \\
\hline 16 & L. firthi (Rowley, Hoang, Dau, Le \& Cao, 2012) & Rowley et al. 2012 \\
\hline 17 & L. fritinniens (Dehling \& Matsui, 2013) & Dehling and Matsui 2013 \\
\hline 18 & L. fuliginosa (Matsui, 2006) & Matsui 2006 \\
\hline 19 & L. fusca Eto, Matsui, Hamidy, Munir \& Iskandar, 2018 & Eto et al. 2018 \\
\hline 20 & L. gracilis (Günther, 1872) & Günther 1872; Dehling 2012b \\
\hline 21 & L. hamidi (Matsui, 1997) & Matsui 1997 \\
\hline 22 & L. heteropus (Boulenger, 1900) & Boulenger 1900 \\
\hline 23 & L. isos (Rowley, Stuart, Neang, Hoang, Dau, Nguyen \& Emmett, 2015) & Rowley et al. 2015a \\
\hline 24 & L. itiokai Eto, Matsui \& Nishikawa, 2016 & Eto et al. 2016 \\
\hline 25 & L. juliandringi Eto, Matsui \& Nishikawa, 2015 & Eto et al. 2015 \\
\hline 26 & L. kajangensis (Grismer, Grismer \& Youmans, 2004) & Grismer et al. 2004 \\
\hline 27 & L. kalonensis (Rowley, Tran, Le, Dau, Peloso, Nguyen, Hoang, Nguyen \& Ziegler, 2016) & Rowley et al. 2016 \\
\hline 28 & L. kecil (Matsui, Belabut, Ahmad \& Yong, 2009) & Matsui et al. 2009 \\
\hline 29 & L. khasiorum (Das, Tron, Rangad \& Hooroo, 2010) & Das et al. 2010 \\
\hline 30 & L. lateralis (Anderson, 1871) & $\begin{array}{c}\text { Anderson } 1871 \text {; Humtsoe et al. } \\
2008\end{array}$ \\
\hline 31 & L. laui (Sung, Yang \& Wang, 2014) & Sung et al. 2014 \\
\hline 32 & L. liui (Fei \& Ye, 1990) & Fei et al. 2009; Sung et al. 2014 \\
\hline 33 & L. macrops (Duong, Do, Ngo, Nguyen \& Poyarkov, 2018) & Duong et al. 2018 \\
\hline 34 & L. maculosa (Rowley, Tran, Le, Dau, Peloso, Nguyen, Hoang, Nguyen \& Ziegler, 2016) & Rowley et al. 2016 \\
\hline 35 & L. mangshanensis (Hou, Zhang, Hu, Li, Shi, Chen, Mo \& Wang, 2018) & Hou et al. 2018 \\
\hline & L. maoershanensis (Yuan, Sun, Chen, Rowley \& Che, 2017) & Yuan et al. 2017 \\
\hline 37 & L. marmorata (Matsui, Zainudin \& Nishikawa, 2014) & Matsui et al. 2014b \\
\hline
\end{tabular}




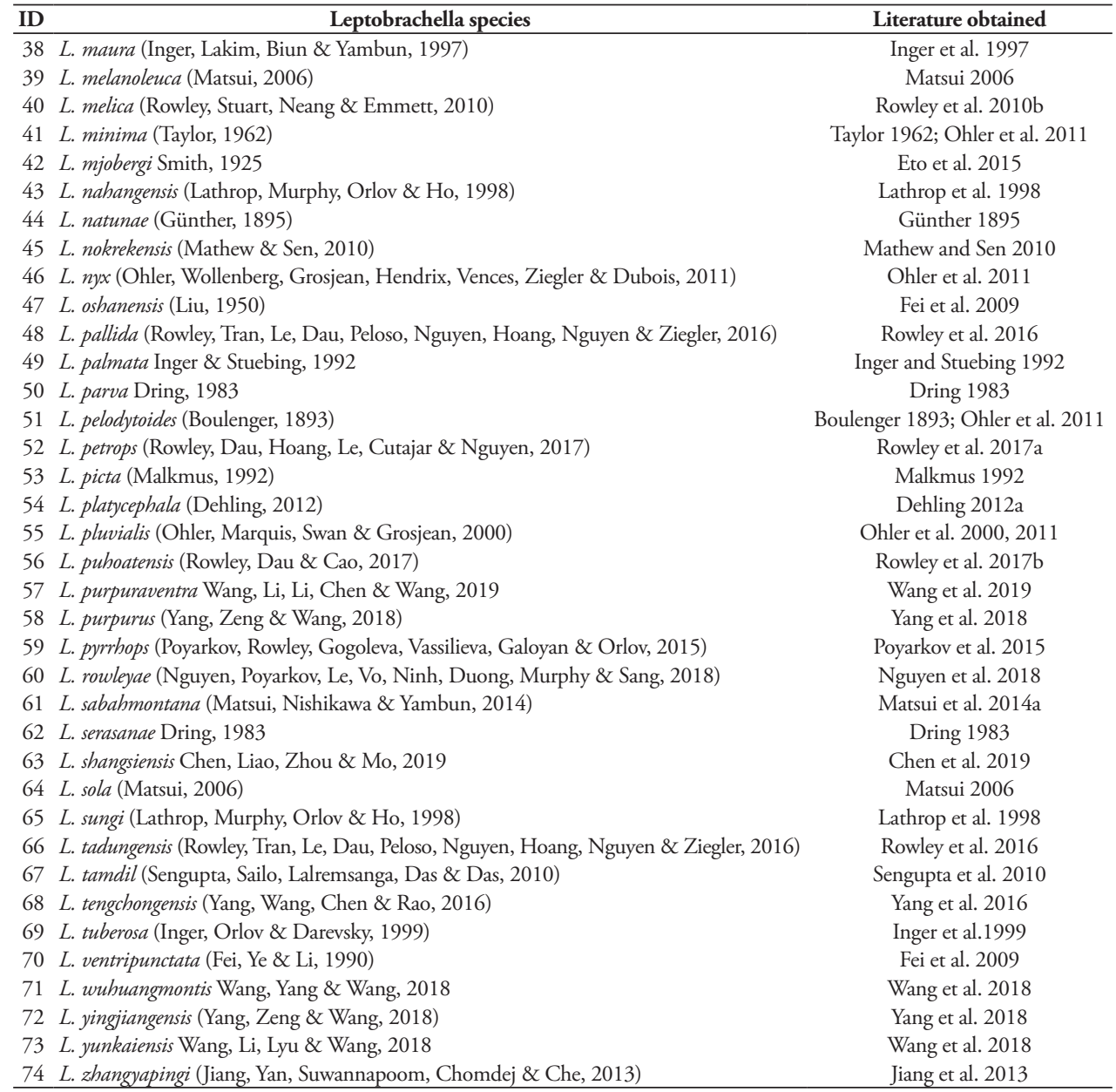

\section{Results}

Phylogenetic trees from Maximum likelihood (ML) and Bayesian inference (BI) were constructed based on DNA sequences of the mitochondrial 16S rRNA gene with a length of $500 \mathrm{bp}$. The trees present identical topologies (Fig. 2) with the clustered population of Leptobrachella from Huoqiuba Nature Reserve, in which L. alpina + L. purpurus and the population of Leptobrachella from Huoqiuba Nature Reserve show relatively high node supporting values (0.68 in BI and 71\% in ML) and exhibit a separate evolving lineage. The smallest pairwise genetic divergence between the population from Suiyang County and all other species of the genus Leptobrachella is $4.71 \%$. This indicates that there is substantial genetic divergence between the species in Leptobrachella and the specimens from Suiyang County, indicating that this new population can be regarded to be a separate lineage and is valid to be described as a new species as below. 


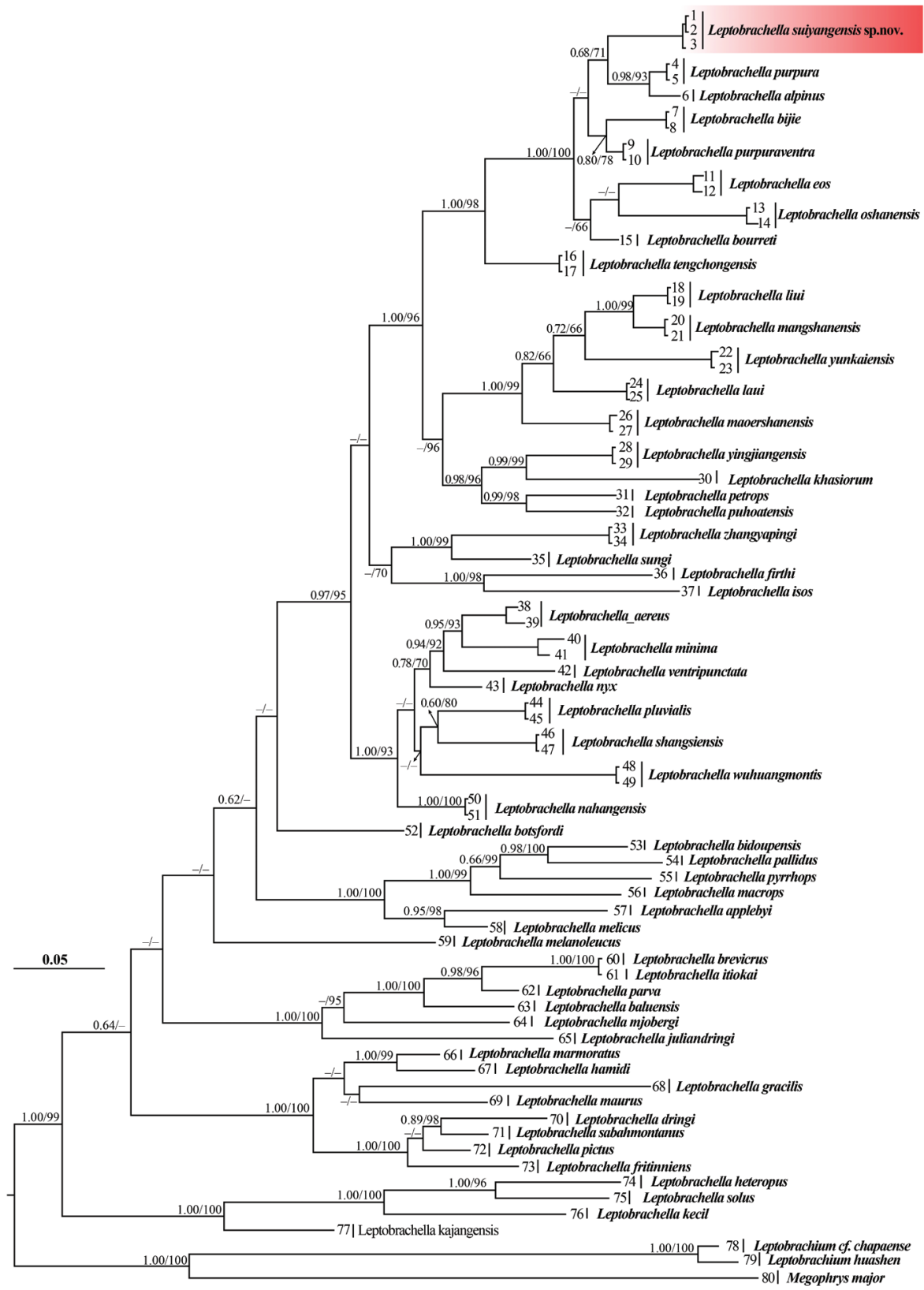

Figure 2. Bayesian inference tree derived from partial DNA sequences of the mitochondrial $16 \mathrm{~S} r$ RNA gene. Numbers before slashes indicate Bayesian posterior probabilities (displayed $>0.60$ values), and numbers after slashes are ultrafast bootstrap support for maximum likelihood (2000 replicates) analyses ( $>60$ retained). The symbol "-" represents value below $0.60 / 60$. The scale bar represents 0.05 nucleotide substitutions per site. 


\section{Taxonomic account}

\section{Leptobrachella suiyangensis sp. nov.} http://zoobank.org/75EDCF88-0293-40E9-83FE-47785145864C

Table 3, Figs 3, 4

Type material. Holotype. GZNU20180606007, adult male, collected by Tao Luo (TL hereafter) on 7 June 2018 from the Huoqiuba Nature Reserve $\left(28.4805^{\circ} \mathrm{N}\right.$, 107.0764ㅌ, 1501 m. a.s.l.; Fig. 1), Suiyang County, Guizhou Province, China.

Paratypes. Five adult males (GZNU20180606002, GZNU20180606005, GZNU20180606006, GZNU20180606008), and three adult females (GZNU20180606001, GZNU20180606003, GZNU20180606004). They were collected from the holotype locality on 6 June 2018.

Etymology. The specific epithet "suiyangensis" refers to the name of the holotype locality, Taibai Town in Suiyang County of Guizohu Province, China. We suggest as its English name "Suiyang Leaf-litter Toad," and its Chinese name as "Sui Yang Zhang Tu Chan (绥阳掌突蟾)”.

Diagnosis. The specimens were assigned to the genus Leptobrachella on the basis of the following characters: (1) small body size; (2) having an elevated inner metacarpal tubercle; (3) having macro-glands on body (including supra-axillary, femoral and ventrolateral glands); (4) lacking vomerine teeth; (5) having small tubercles on eyelids; (6) anterior tip of snout with whitish vertical bar (Dubois 1983; Matsui 1997, 2006; Lathrop et al. 1998; Delorme et al. 2006; Das et al. 2010). Leptobrachella suiyangensis sp. nov. can be distinguished from its congeners by referring to the following characters: (1) small body size (SVL 28.7-29.7 $\mathrm{mm}$ in males, 30.5-33.5 $\mathrm{mm}$ in females); (2) dorsal skin shagreened, with some of the granules forming longitudinal short skin ridges; (3) tympanum distinctly discernible, slightly concave, with a deep, black, supratympanic line; (4) ventrolateral glands are distinct, forming a dotted line; (5) dorsal surface shagreened and granular, lacking enlarged tubercles or warts, with some of the granules forming short longitudinal folds; (6) flanks with several distinct and large dark blotches; (7) ventral surface of throat grey-white, and surface of chest and belly yellowish creamy-white with marbled texture or with irregular light brown speckling; (8) supra-axillary, femoral, pectoral and ventrolateral glands are distinctly visible; (9) absence of webbing and lateral fringes on fingers, and toes feature rudimentary webbing and a weak lateral fringes; (10) relatively short hindlimbs (TIB/SVL ratio in males $0.46-0.47)$; (11) longitudinal ridges under the toes are interrupted at the articulations; (12) relative finger lengths I $<$ II $<$ IV $<$ III, relative toe lengths $\mathrm{I}<\mathrm{II}<\mathrm{V}<\mathrm{III}<$ IV; (13) dorsum greyish-brown, with small light-orange granules and distinct darker brown markings scattered with irregular light-orange pigmentation, and bicolored iris, coppery orange on the upper half and silver grey on the lower half.

Description of the holotype. GZNU20180606007 (adult male), small body size (SVL $28.7 \mathrm{~mm}$ ); the head length is slightly larger than the head width (HDL/HDW ratio 1.06); the snout is slightly protruding, projecting beyond the margin of the lower 


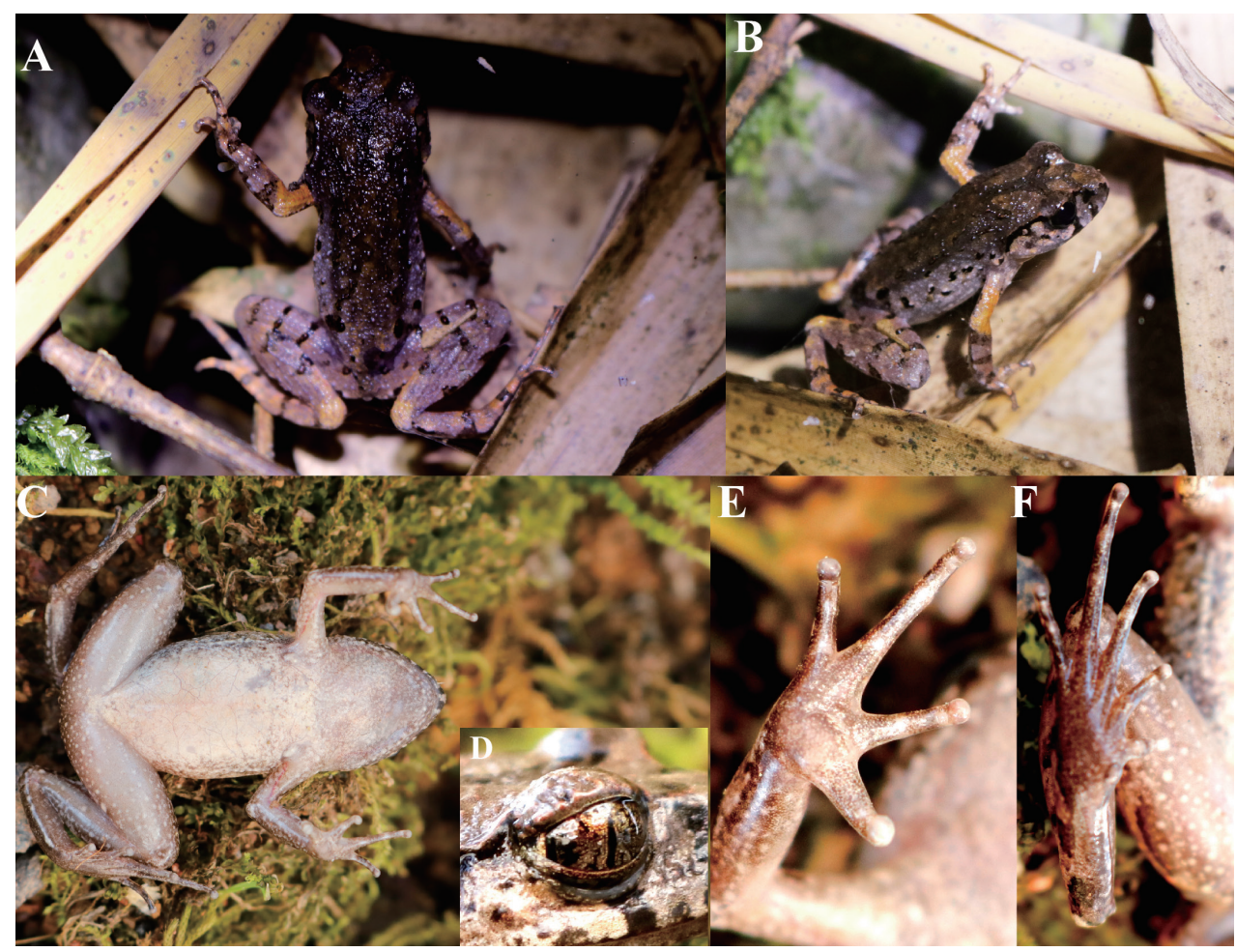

Figure 3. Holotype of Leptobrachella suiyangensis sp. nov. (GZNU20180606007) in life. A Dorsal view B Dorsolateral view C Ventral view D Right eye shown iris coloration E Volar view of the left hand F Plantar view of the left foot.

jaw; the nostril is between the snout and the eye (NSL/NEL ratio 0.39); the canthus rostralis is gently rounded; the loreal region is slightly concave; the interorbital space is flat; larger (IOD $2.9 \mathrm{~mm}$ ) than the upper eyelid (1.6 $\mathrm{mm}$ in width), and the internarial distance is $2.8 \mathrm{~mm}$; with vertical pupil; snout length is slightly larger than eye diameter (SNT/EYE ratio 1.71); tympanum is distinct and rounded, its diameter (TMP $2.1 \mathrm{~mm}$ ) is smaller than that of the eye diameter (EYE $2.4 \mathrm{~mm}$ ) and longer than the tympanum-eye distance (TMP/TEY ratio 1.91); deep black supratympanic line is present; weakly black supratympanic line exists (Fig. 3C); tympanic rim is distinctly elevated relative to the skin of the temporal region; supratympanic ridge is distinct, extending from the eye to the supra-axillary gland; a few indistinct tubercles present on supratympanic ridge; absent vomerine teeth; vocal sac openings is slit-like, located posterior-laterally on the floor of the mouth close to the margins of the mandible; long and wide tongue, with a small shallow notch at the posterior tip.

The tips of the fingers are rounded, slightly swollen; relative finger lengths are presented as: I $<\mathrm{II}<\mathrm{IV}<\mathrm{III}$; nuptial pad is absent; absent subarticular tubercles (Fig. 3F); a large, round inner palmar tubercle is distinctly separated from a small, round outer palmar tubercle; finger webbing and dermal fringes absent. Toe tips are similar to those 
of the fingers; the relative toe length is presented as: $\mathrm{I}<\mathrm{II}<\mathrm{V}<\mathrm{III}<\mathrm{IV}$; absent subarticular tubercles; distinct dermal ridges present under the $3^{\text {rd }}$ to $5^{\text {th }}$ toes; pronounced larger, oval inner metatarsal tubercle, outer metatarsal tubercle is absent; rudimentary toe webbing; weak lateral fringes present on all toes. Tibia is slightly shorter than half of the snoutvent length (TIB/SVL ratio 0.46); tibiotarsal articulation reaches to the anterior eye; heels meet each other when thighs are appressed at right angles referring to the body.

Dorsal skin is shagreened and scattered with fine and rounded granules, some of the granules forming short longitudinal folds; ventral skin smooth; large pectoral gland, elongated oval, $1.5 \mathrm{~mm}$ in length; small femoral gland, rounded, $0.7 \mathrm{~mm}$ in diameter, situated on the posteroventral surface of the thigh, closer to tibiotarsal articulation than to the vent; risen supra-axillary gland, $1.3 \mathrm{~mm}$ in diameter; ventrolateral gland is distinct as small white dots forming an incomplete line (Fig. 3D).

Measurements of holotype (in mm). Holotype: SVL 28.7, HDL 9.9, HDW 9.3, SNT 4.1, EYE 2.4, IOD 2.9, INT 2.8, UEW 1.6, NEL 2.8, NSL 1.1, TMP 2.1, TEY 1.1, TIB 13.1, HND 7.2, LAHL 13.4, HLL 43.3, FOT 12.5.

Coloration of holotype in life. Dorsal skin purple-brown; brown-purplish with dark-brown marks between the eyes and the scapular region, which are scattered with some deep yellow-orange granules more concentrated on the upper eyelid (Fig. 3C). A dark brown $\Upsilon$-pattern exists between eyes, linked with dark brown W-shaped marks between axillae. Tympanum is light brown-grey; black-brown tubercles present on dorsum of the body and the limb; those on dorsal side are much more distinct and dense; anterior upper lip features distinct blackish-brown patches; transverse dark-brown bars exist on dorsal surface of the limbs two or three (elbow and upper arms are an exception); indistinct black or brown blotches present on the flanks from groin to axilla; elbow and upper arms have no dark bars but with distinct dark-orange coloration; fingers and toes show indistinct brown blotches; a black spot is present on the loreal region; lower edge of the upper drum ridge is prominently black; ventral surface of the throat is grey-white, and surface of chest and belly is yellowish creamy-white, ventral part with distinct or indistinct light brown speckling mixed with marble texture; ventral surface of the thighs is dark grey and scattered with small light white spots. Supra-axillary gland milky yellow; iris is bicolored, coppery orange on the upper half and silver grey on the lower half.

Coloration of holotype in preservative. In preservation, there are dark brown marks on the dorsum and flanks; dorsum of the body and hindlimbs are dark brown, while dorsum of the forelimbs is yellowish brown; transverse bars on the limbs become more distinct, and dark-brown patterns, marks and spots on the back are indistinct; ventral surface of the body is yellowish brown with brown marbling on the sides and chest; orange supra-axillary, femoral, pectoral and ventrolateral glands fade to greyish white.

Variations. Measurements of the type series are shown in Table 4. Females (mean of SVL $(32.0 \pm 1.5 \mathrm{~mm}, n=3)$ have larger body size than males (mean of SVL 29.2 $\pm 0.4 \mathrm{~mm}, n=5$ ) (Table 4). In life (Fig. 5), all paratypes match overall characters of the holotype, except the surface of the belly that is scattered with brown speckling 

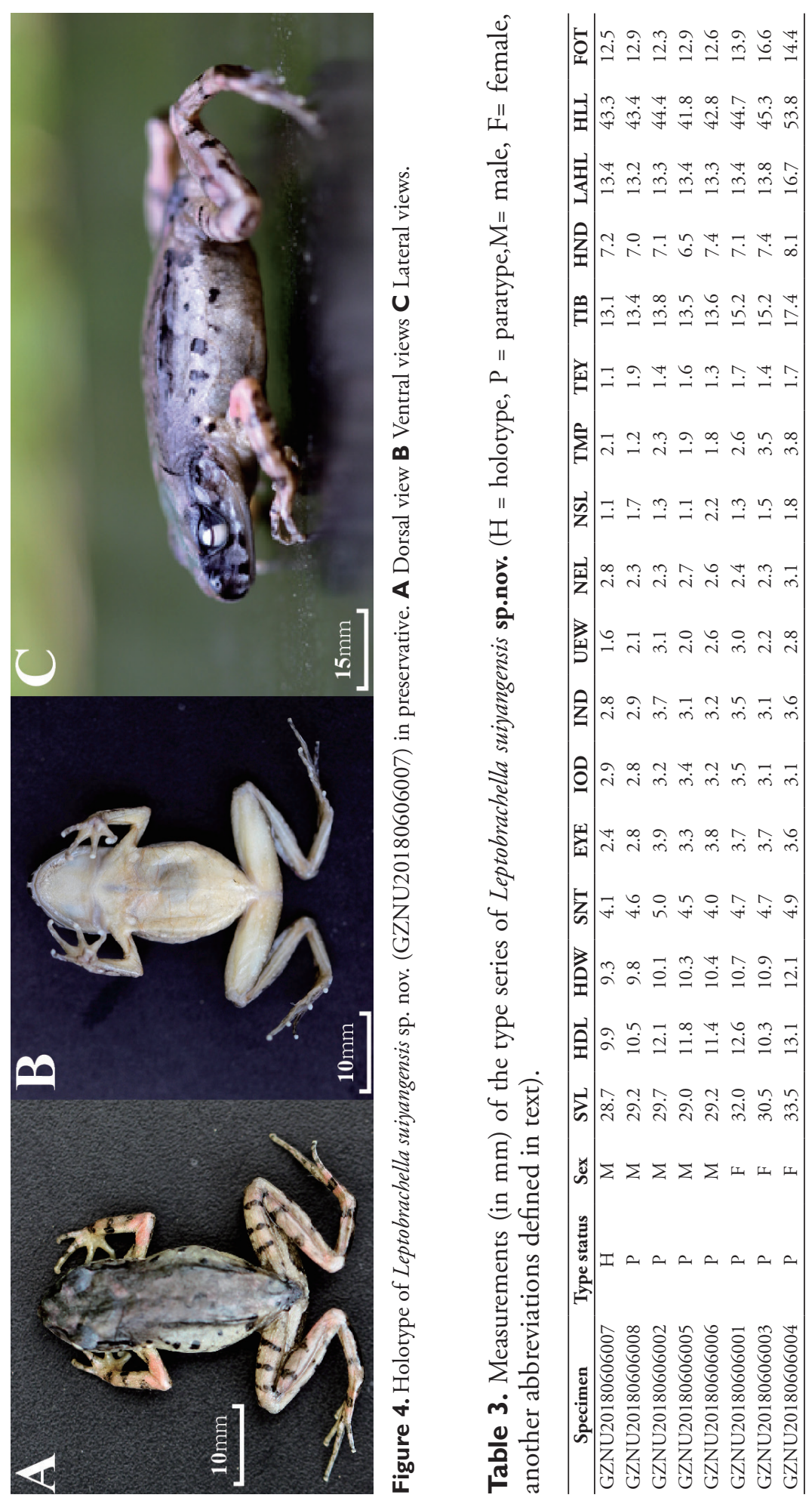


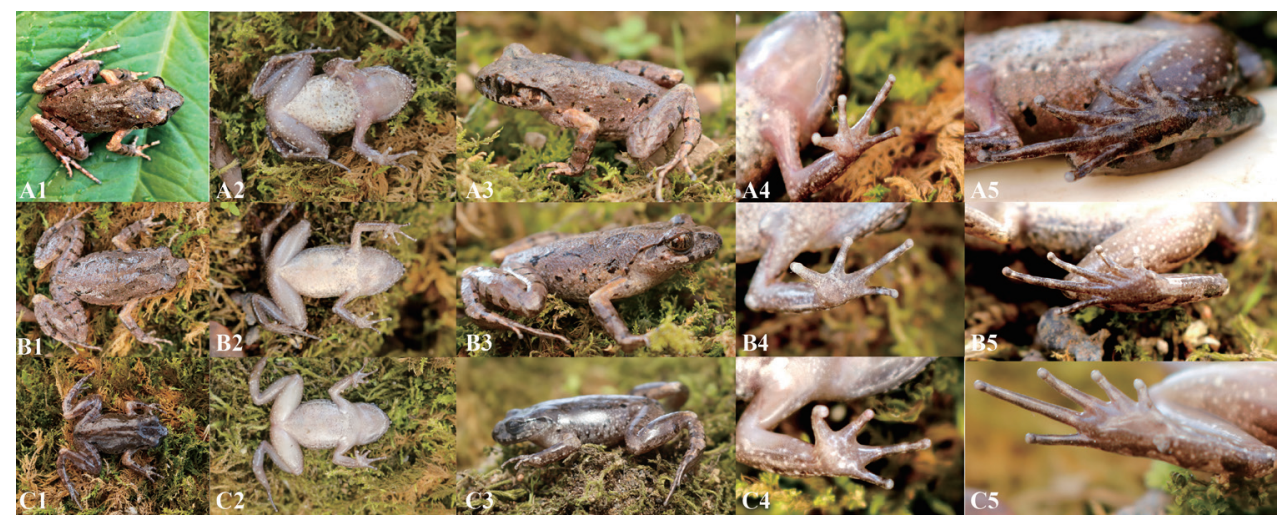

Figure 5. Paratypes of Leptobrachella suiyangensis sp. nov. in life. A GZNU20180606005, adult male (A), (B) GZNU20180606002, adult male C GZNU20180606003, adult female.

Table 4. Measurements (in $\mathrm{mm}$ ), and body proportions of Leptobrachella suiyangensis sp.nov. from Suiyang County, Guizhou Province, China.

\begin{tabular}{lcc}
\hline Measurements & Males Range $(\mathbf{m e a n} \pm \mathbf{S D}) \mathbf{n}=\mathbf{5}$ & Females Range $(\mathbf{m e a n} \pm \mathbf{S D}), \mathbf{n}=\mathbf{3}$ \\
\hline SVL & $28.7-29.7(29.2 \pm 0.4)$ & $30.5-33.5(32.0 \pm 1.5)$ \\
HDL & $9.9-12.1(11.1 \pm 0.9)$ & $10.3-13.1(12.0 \pm 1.5)$ \\
HDW & $9.3-10.4(10.0 \pm 0.4)$ & $10.7-12.1(11.2 \pm 0.8)$ \\
SNT & $4.0-5.0(4.4 \pm 0.4)$ & $4.7-4.9(4.8 \pm 0.1)$ \\
EYE & $2.4-3.9(3.2 \pm 0.6)$ & $3.6-3.7(3.7 \pm 0.1)$ \\
IOD & $2.8-3.4(3.1 \pm 0.2)$ & $3.1-3.5(3.2 \pm 0.2)$ \\
INT & $2.8-3.7(3.1 \pm 0.4)$ & $3.1-3.6(3.4 \pm 0.3)$ \\
UEW & $1.6-3.1(2.3 \pm 0.6)$ & $2.2-3.0(2.7 \pm 0.4)$ \\
NEL & $2.3-2.8(2.5 \pm 0.2)$ & $2.3-3.1(2.6 \pm 0.4)$ \\
NSL & $1.1-2.2(1.5 \pm 0.5)$ & $1.3-1.8(1.5 \pm 0.3)$ \\
TMP & $1.2-2.3(1.9 \pm 0.4)$ & $2.6-3.8(3.3 \pm 0.6)$ \\
TEY & $1.1-1.9(1.5 \pm 0.3)$ & $1.4-1.7(1.6 \pm 0.2)$ \\
TIB & $13.1-13.8(13.5 \pm 0.3)$ & $15.2-17.4(15.9 \pm 1.3)$ \\
HND & $6.5-7.4(7.0 \pm 0.3)$ & $7.1-8.1(7.5 \pm 0.5)$ \\
LAHL & $13.2-13.4(13.3 \pm 0.1)$ & $13.4-16.7(14.6 \pm 1.8)$ \\
HLL & $41.8-44.4(43.1 \pm 0.9)$ & $44.7-53.8(47.9 \pm 5.1)$ \\
FOT & $12.3-12.9(12.6 \pm 0.3)$ & $13.9-16.6(15.0 \pm 1.4)$ \\
HDL/HDW & $1.06-1.20(1.12 \pm 0.06)$ & $0.90-1.20(1.07 \pm 0.15)$ \\
HDL/SVL & $0.34-0.41(0.38 \pm 0.03)$ & $0.30-0.40(0.37 \pm 0.06)$ \\
SNT/HDL & $0.35-0.44(0.40 \pm 0.03)$ & $0.40-0.50(0.43 \pm 0.06)$ \\
SNT/EYE & $1.05-1.71(1.41 \pm 0.27)$ & $1.30-1.40(1.33 \pm 0.06)$ \\
EYE/TMP & $1.14-2.33(1.80 \pm 0.45)$ & $1.00-1.40(1.17 \pm 0.21)$ \\
EYE/SNT & $0.59-0.95(0.73 \pm 0.15)$ & $0.70-0.80(0.77 \pm 0.06)$ \\
TMP/EYE & $0.43-0.88(0.59 \pm 0.18)$ & $0.70-1.10(0.93 \pm 0.21)$ \\
TIB/SVL & $0.46-0.47(0.46 \pm 0.01)$ & 0.50 \\
LAHL/SVL & $0.45-0.47(0.46 \pm 0.01)$ & $0.40-0.50(0.47 \pm 0.06)$ \\
HLL/SVL & $1.44-1.51(1.48 \pm 0.03)$ & $1.40-1.60(1.50 \pm 0.10)$ \\
TIB/HLL & $0.30-0.32(0.31 \pm 0.01)$ & 0.30 \\
\hline
\end{tabular}

in the holotype (that for females is more distinct; GZNU20180606001). Under the condition of preservation, however, some specimens become slightly darker brown compared to the holotype. 
Distribution and habitats. Currently, Leptobrachella suiyangensis sp. nov. is known only from its holotype locality, Huoqiuba Nature Reserve, Suiyang County, Guizhou Province, China (Fig. 1). The specimens were collected in a stream (ca $1.5 \mathrm{~m}$ in width and ca $10 \mathrm{~cm}$ in depth) and from nearby well-preserved bamboo forests $(1501 \mathrm{~m}$ a.s.l.). During June, males were calling from under bamboo leaves; others perch on or under rocks by the side of the stream.

\section{Comparisons}

Leptobrachella suiyangensis sp. nov. differs from all other species of Leptobrachella based on morphological and molecular evidence. Phylogenetically, L. suiyangensis sp. nov., L. alpina and L. purpurus form a clade. Genetically, among this clade, the smallest genetic distance, at $5.49 \%$, is between $L$. suiyangensis sp. nov. and $L$. alpina, and the largest genetic distance is $6.27 \%$ (L. suiyangensis sp. nov. and L. purpurus). Morphologically, the new species can be distinguished from L. alpina by having a larger body size of males (28.7-29.7 $\mathrm{mm}$ vs $24.0-26.4 \mathrm{~mm}$ ); having narrower lateral fringes on the toes of the male (vs wide in males); dorsum purple-brown to dark purple-brown or grey-purple ground colour; ventral yellowish creamy-white with marbled texture on the chest and belly or with irregular light-brown speckling (vs almost uniformly graybrown on dorsal part, ventral nearly immaculately creamy white, brown specking on margins); ventrolateral glands are characterized by small white dots forming an incomplete line (vs small white dots forming a complete line longitudinally); shoulder-gland is orange-yellow (vs white, around gland); head length greater than head width, HDL/ HDW ratio 1.12 (vs head length equal to head width, HDL/HDW ratio 1.00). The new species can be distinguished from L. purpurus by body size of males (28.7-29.7 $\mathrm{mm}$ vs $25.0-27.5 \mathrm{~mm}$ ); having narrow lateral fringes on the toes of males (vs wide in males); dorsum purple-brown to dark purple-brown or grey-purple ground color, ventral yellowish creamy-white with marbled texture on the chest and belly or with irregular light-brown speckling (vs dorsum coloration purplish brown, ventral side dull white with an indistinct grey dusting); throat immaculate gray (vs throat immaculate pinkish; almost dark orange-yellow on the upper arm (vs upper arms with distinct coppery orange coloration); dark bars on dorsal surface of tibia and tarsus very narrow, especially those on dorsal skin of tarsus (vs relatively broader dark bars on dorsal surface of tibia and tarsus); tibiotarsal articulation reaches to the anterior eye (vs tibiotarsal articulation reaches to posterior corner of the eye); relative length of fingers I $<$ II $<$ IV $<$ III (vs I = II = IV < III).

Compared with the 26 known congeners in the genus Leptobrachella found south of the Isthmus of Kra, referring to the presence or absence of supra-axillary and ventrolateral glands, L. suiyangensis sp. nov. can be easily distinguished from $L$. arayai, L. dringi, L. fritinniens, L. gracilis, L. hamidi, L. heteropus, L. kajangensis, L. kecil, $L$. marmorata, L. maura, L. melanoleuca, L. picta, L. platycephala, L. sabahmontana and $L$. sola, all of which are lack of supra-axillary and ventrolateral glands (Dubois et al. 2010; 
Dehling and Matsui 2013; Matsui et al. 2014). As for the comparison referring to the body size, the new species shows a significantly larger body size (SVL, 28.7-29.7 mm in males) than L. baluensis (14.9-15.9 mm in males), L. brevicrus (17.1-17.8 $\mathrm{mm}$ in males), L. itiokai (15.2-16.7 mm In males), L. juliandringi (17.0-17.2 mm in males), L. mjobergi (15.7-19.0 $\mathrm{mm}$ in males), L. natunae (17.6 $\mathrm{mm}$ in one adult male), L. parva (15.0-16.9 $\mathrm{mm}$ in males), L. palmata (14.4-16.8 $\mathrm{mm}$ in males), L. serasanae (16.9 $\mathrm{mm}$ in one adult male), and Leptobrachella sp. 3 "baluensis" (15.0-16.0 $\mathrm{mm}$ in males).

From the remaining 48 known congeners in the genus Leptobrachella found north of the Isthmus of Kra (Table 5) with SVL 28.7-29.7 mm in males and SVL 30.5-33.5 $\mathrm{mm}$ in females, L. suiyangensis sp. nov. can be distinguished from the larger L. bourreti (42.0-45.0 mm in females), L. eos (33.1-34.7 $\mathrm{mm}$ in males and 40.7 in one female), L. lateralis (36.6 $\mathrm{mm}$ in females), L. nahangensis ( $40.8 \mathrm{~mm}$ in one male), L. nyx (37.0$41.0 \mathrm{~mm}$ in females), L. pyrrhops (30.8-34.3 $\mathrm{mm}$ in males), L. sungi (48.3-52.7 $\mathrm{mm}$ in males and 56.7-58.9 $\mathrm{mm}$ in females), L. tamdil (32.3 $\mathrm{mm}$ in males) and L. zhangyapingi (45.8-52.5 $\mathrm{mm}$ in males), and from the smaller L. alpina (24.0-26.4 $\mathrm{mm}$ in males), L. applebyi (19.6-22.3 $\mathrm{mm}$ in males and 21.7-26.4 $\mathrm{mm}$ in females), L. ardens (21.3-24.7 $\mathrm{mm}$ in males and $24.5 \mathrm{~mm}$ in female), L. bidoupensis (18.5-25.4 $\mathrm{mm}$ in males and 29.2-29.4 mm in females), L. khasiorum (24.5-27.3 $\mathrm{mm}$ in males), L. laui (24.8-26.7 $\mathrm{mm}$ in males), L. maculosa (24.2-26.6 in males and $27.0 \mathrm{~mm}$ in one female), L. melica (19.5-22.7 $\mathrm{mm}$ in males), L. maoershanensis (29.1 $\mathrm{mm}$ in one female), L. petrops (23.6-27.6 $\mathrm{mm}$ in males), L. pluvialis (21.3-22.3 $\mathrm{mm}$ in males), L. purpurus (25.0-27.5 mm in males), L. rowleyae (23.1-28.1 $\mathrm{mm}$ in males and $27.0-27.8 \mathrm{~mm}$ in females), L. ventripunctata (25.5-28.0 mm in males), L. tengchongensis (23.9-26.0 mm in males and 28.8-28.9 $\mathrm{mm}$ in females) and L. yingjiangensis (25.7-27.6 $\mathrm{mm}$ in males).

In having irregular, light-brown speckling on the flanks, the new species differs from L. aerea, L. botsfordi, L. crocea, L. firthi, L. isos, L. pallida, L. petrops and L. tuberosa, all of which lack distinct irregular, light-brown speckling on the flanks. By having rudimentary webbing on the toes, the new species differs from $L$. kalonensis, $L$. oshanensis, L. pallida, L. petrops, and L. tadungensis, all of which lack webbing on the toes; and from L. pelodytoides, which has wide webbing on the toes. By having narrow lateral fringes on toes, the new species differs from L. ardens, L. eos, L. firthi, L. isos, L. khasiorum, L. laui, L. liui, L. purpurus, L. tamdil, L. yingjiangensis and L. yunkaiensis, all of which have wide lateral fringes on the toes; from L. bidoupensis, L. bourreti, $L$. fuliginosa and L. mangshanensis, all of which have weak lateral fringes on the toes; and from L. crocea, L. kalonensis, L. lateralis, L. macrops, L. minima, L. nyx, L. oshanensis, L. pallida, L. pyrrhops, L. tadungensis, L. tuberosa, and L. ventripunctata, all of which lack lateral fringes on the toes. By having dorsal surface shagreened with small granules, and in lacking enlarge tubercles or warts, the new species differs from L. applebyi, L. bidoupensis, L. kalonensis, L. melica, L. minima, L. nahangensis, L. shangsiensis and L. tadungensis, all of which have the dorsum smooth, and L. alpina (dorsum smooth, some with small warts), L. fuliginosa (dorsum smooth with fine tubercles), L. laui (dorsum with round granular tubercle, lacking skin ridges), L. liui (dorsum with round tubercles), L. macrops (dorsum roughly granular with large tubercles), L. maoershanensis 


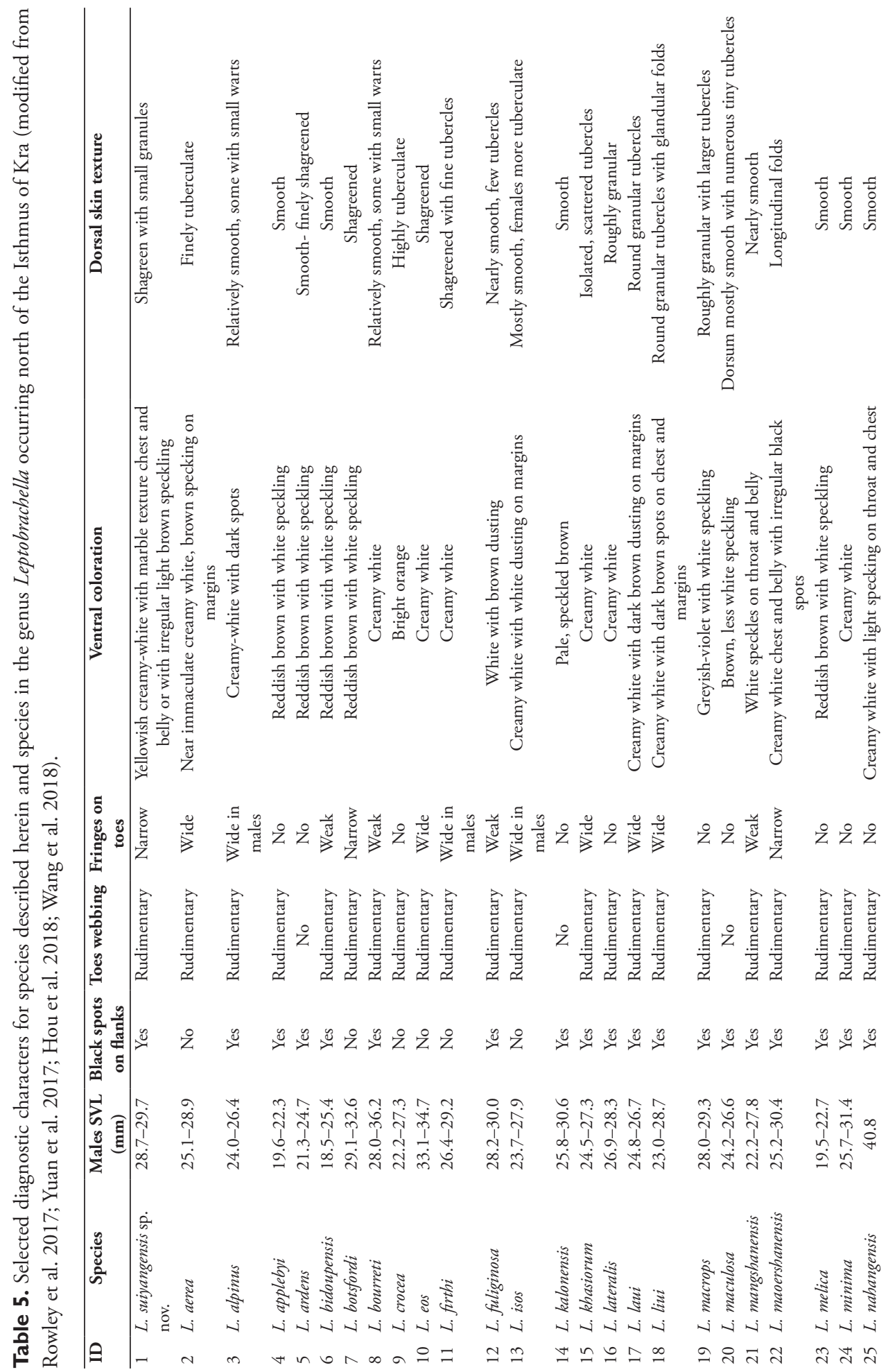



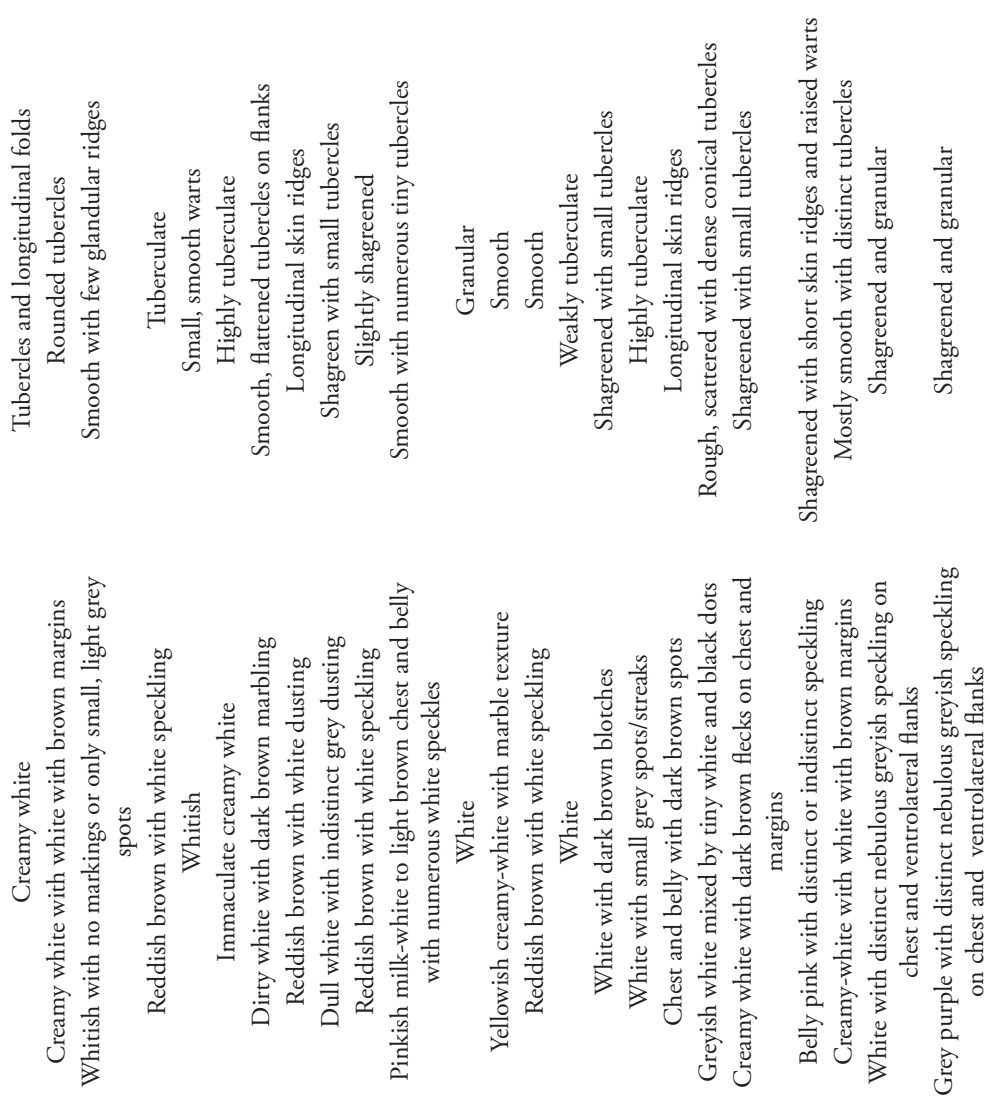

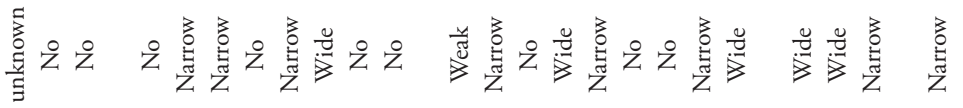

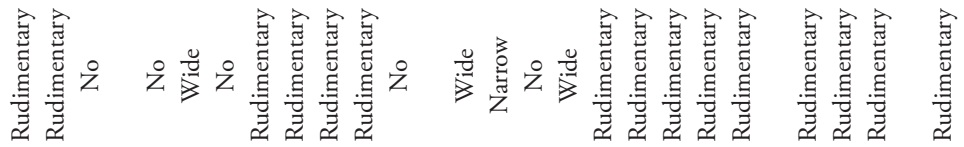

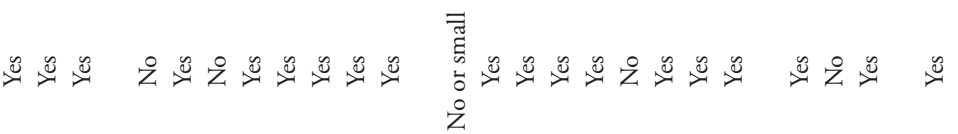

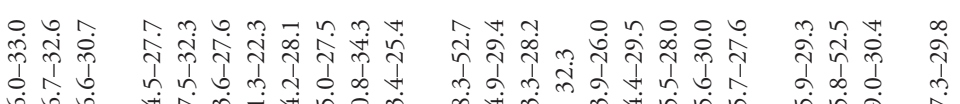
نं

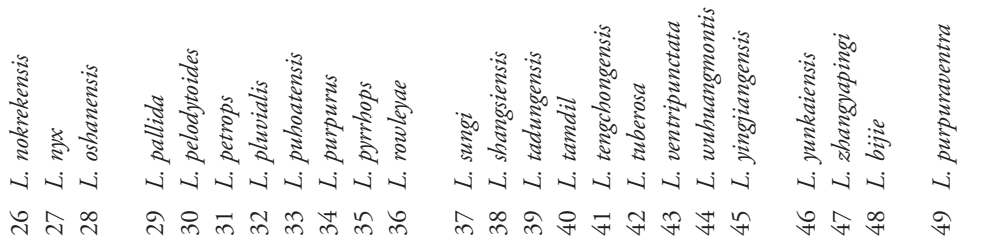


(dorsum smooth with small warts), L. nokrekensis (dorsum tubercles and longitudinal folds), L. pelodytoides (dorsum with small, smooth warts), L. puhoatensis (dorsum longitudinal skin ridges), L. tuberosa (dorsum highly tuberculate), L. yunkaiensis (dorsum with raised warts), L. wuhuangmontis (dorsum rough with conical tubercles), and $L$. bijie and $L$. purpuraventra (dorsum shagreened and granular). By the yellowish creamywhite with marbled chest and belly or with irregular light-brown speckling, the new species differs from L. alpinus, L. applebyi, L. ardens, L. bidoupensis, L. botsfordi and L. pyrrhops (ventral reddish brown with white speckling), L. aerea (ventral nearly immaculate creamy-white with brown specking on margins), L. bijie (ventral white with distinct nebulous greyish speckling on chest and ventrolateral flanks), L. crocea (ventral bright orange), L. khasiorum, L. nokrekensis and L. yingjiangensis (ventral creamy white), L. macrops (ventral greyish-violet with white speckling), L. puhoatensis (ventral reddish-brown with white dusting), L. purpurus (ventral dull white with indistinct grey dusting), L. purpuraventra (ventral grey-purple with distinct nebulous greyish speckling on the chest and ventrolateral flanks), L. tuberosa (ventral white with small grey spots and streaks), $L$. ventripunctata (chest and belly with large dark brown spots), $L$. wuhuangmontis (ventral greyish white), and L. yunkaiensis (belly pink with speckling). A comparative morphological data (selection) of Leptobrachella suiyangensis sp. nov. and 48 recognized Leptobrachella species occurring north of the Isthmus of Kra are listed in Table 5.

\section{Discussion}

Phylogenetic analyses based on mitochondrial DNA and nuclear DNA all suggested that the new species belongs to Leptobrachella but is separate from its congeners. Genetic distance of the $16 \mathrm{~S}$ rRNA gene between the new species and its closely related species (L. bijie, L. purpuraventra, L. alpina and L. purpurus) was 4.71-6.27\%, within the expected range of interspecific divergences in amphibians (Fouquet et al. 2007), and this genetic distance is much higher than between many sister species, of which, most species have been completely recognized as valid species. For example, in Leptobrachella, the $p$-distance $=2.35 \%$ between L. purpurus and L. alpina. Finally, a series of morphological characters were found to be different between the new species and its congenerson. All in all, multiple pieces of evidence support the validity of the new species.

The new species described in this study increases the number of species of Leptobrachella to 75, with 21 recorded from China (Fei et al. 2012; Sung et al. 2014; Yang et al. 2016, 2018; Yuan et al. 2017; Hou et al. 2018; Wang et al. 2018, 2019; Chen et al. 2018, 2019; Frost 2019). Before the description of the new species herein, only 12 species were recorded from southwest China. This highlights the underestimation of the species diversity of the genus Leptobrachella. Additional field surveys are required to understand the true diversity of amphibians in this genus, which will be useful for conservation strategies. 
Studies on the taxonomy and phylogeny of the genus Leptobrachella were difficult to perform because of the morphological conservativeness of the species; in the field, many species appear to be very similar morphologically, and there exist sympatric species. This likely hinders our understanding of these cryptic species (Ohler et al. 2010; Sung et al. 2014; Yang et al. 2016, 2018; Yuan et al. 2017; Hou et al. 2018; Wang et al. 2018, 2019; Chen et al. 2019). The high species diversity and the degree of endemism indicated that the speciation pattern and sympatry mechanism of species in the genus Leptobrachella also need additional investigation.

Currently, to our knowledge, L. suiyangensis sp. nov. is restricted to rocky streams in bamboo forests. However, the type locality of L. suiyangensis sp. nov. has faced habitat loss and human disturbance, such as artificial grazing and herb collection, which could possibly threaten this species. Leptobrachella suiyangensis sp. nov. is range-restricted to Kuankuoshui National Nature Reserve, which borders the nearby Huoqiuba Nature Reserve and is in the eastern Ta-lou Mountains. These areas feature subtropical evergreen broad-leaved forest and evergreen deciduous broad-leaved mixed forest. Thus, it is likely that other populations of $L$. suiyangensis sp. nov. may be discovered in the Kuankuoshui Nature Reserve in the near future.

\section{Acknowledgements}

This project was supported by the key project of science-technology of basic condition platform granted by The Ministry of Science and Technology of the People's Republic of China (Grant No. 2005DKA21402); The National Top Discipline Construction Project of Guizhou Province; Geography in Guizhou Normal University (85 2017 Qianjiao Keyan Fa); and The Project of Science and Technology Program of Guizhou Province, "Study of biological and ecological vales for Fanjingshan World Natural Heritage Nomination of Tongren City (3052 2015 Qiankehe SY)". We thank Bo Song and Hongtao Cui for their help in sample collection. We thank Professor Ruliang Pan and LetPub (http:// www.letpub.com) for its linguistic assistance during the preparation of this manuscript.

\section{References}

Anderson J (1871) A list of the reptilian accession to the Indian Museum, Calcutta from 1865 to 1870 , with a description of some new species. Journal of the Asiatic Society of Bengal 40: $12-39$.

Boulenger GA (1893) Concluding report on the reptiles and batrachians obtained in Burma by Signor L. Fea dealing with the collection made in Pegu and the Karin Hills in 1887-88. Annali del Museo Civico di Storia Naturale di Genova 13: 304-347.

Boulenger GA (1900) Descriptions of new batrachians and reptiles from the Larut Hills, Perak. Annals and Magazine of Natural History (Series 7) 6: 186-194. https://doi. org/10.1080/00222930008678356 
Boulenger GA (1908) A revision of the Oriental pelobatid batrachians (genus Megalophrys). Proceedings of the Zoological Society of London 1908: 407-430. https://doi. org/10.1111/j.1096-3642.1908.tb01852.x

Bourret R (1937) Notes herpétologiques sur l'Indochine française. XIV. Les batraciens de la collection du Laboratoire des Sciences Naturelles de l'Université. Descriptions de quinze especes ou variétés nouvelles. Annexe au Bulletin Général de l'Instruction Publique, Hanoi 1937: 5-56.

Chen JM, Poyarkov NJ, Suwannapoom C, Lathrop A, Wu YH, Zhou WW, Yuan ZY, Jin JQ, Chen HM, Liu HQ, Nguyen TQ, Nguyen SN, Duong TV, Eto K, Nishikawa K, Matsui M, Orlov NL, Stuart BL, Brown RM, Rowley J, Murphy RW, Wang YY, Che J (2018) Large-scale phylogenetic analyses provide insights into unrecognized diversity and historical biogeography of Asian leaf-litter frogs, genus Leptolalax, (Anura: Megophryidae). Molecular Phylogenetics and Evolution 124: 162-171. https://doi.org/10.1016/j. ympev.2018.02.020

Chen, W, Liao XW, Zhou SC, Mo YM (2019) A new species of Leptobrachella (Anura: Megophryidae) from southern Guangxi, China. Zootaxa 4563(1): 67-82. https://doi. org/10.11646/zootaxa.4563.1.3

Dring J (1983) Frogs of the genus Leptobrachella (Pelobatidae). Amphibia-Reptilia 4(2): 89102. https://doi.org/10.1163/156853883X00012

Dubois A (1983) Note préliminaire sur le genre Leptolalax Dubois, 1980 (Amphibiens, Anoures), avec diagnose d'une espèce novelle du Vietnam. Alytes 2: 147-153.

Dubois A (1987) Miscellanea taxinomica batrachologica (I). Alytes. Paris 5[1986]: 7-95.

Delorme M, Dubois A, Grosjean S, Ohler A (2006) Une nouvelle ergotaxinomie des Megophryidae (Amphibia, Anura). Alytes 24(1-4): 6-21.

Das I, Tron RKL, Rangad D, Hooroo RN (2010) A new species of Leptolalax (Anura: Megophryidae) from the sacred groves of Mawphlang, Meghalaya, north-eastern India. Zootaxa 2339: 44-56. https://doi.org/10.11646/zootaxa.2339.1.2

Dehling JM (2012a) Eine neue Art der Gattung Leptolalax (Anura: Megophryidae) vom Gunung Benom, Westmalaysia/A new species of the genus Leptolalax (Anura: Megophryidae) from Gunung Benom, Peninsular Malaysia. Sauria 34: 9-21.

Dehling JM (2012b) Redescription of Leptolalax gracilis (Günther, 1872) from Borneo and taxonomic status of two populations of Leptolalax (Anura: Megophryidae) from Peninsular Malaysia. Zootaxa 3328: 20-34. https://doi.org/10.11646/zootaxa.3328.1.2

Dubois A, Grosjean S, Ohler A, Adler K, Zhao EM (2010) The nomenclatural status of some generic nomina of Megophryidae (Amphibia, Anura). Zootaxa 2493: 66-68. https://doi. org/10.11646/zootaxa.2493.1.6

Dehling JM, Matsui M (2013) A new species of Leptolalax (Anura: Megophryidae) from Gunung Mulu National Park, Sarawak, East Malaysia (Borneo). Zootaxa 3670(1): 33-44.

Duong VT, Do DT, Ngo CD, Nguyen TQ, Poyarkov Jr, NA (2018) A new species of the genus Leptolalax (Anura: Megophryidae) from southern Vietnam. Zoological Research 39(3): 181-196. https://doi.org/10.24272/j.issn.2095-8137.2018.009

Edgar RC (2004) MUSCLE: multiple sequence alignment with high accuracy and high throughput. Nucleic Acids Research 32(5): 1792-1797. https://doi.org/10.1093/nar/gkh340 
Eto K, Matsui M, Nishikawa K (2015) Description of a new species of the genus Leptobrachella (Amphibia, Anura, Megophryidae) from Borneo. Current Herpetology 34(2): 128-139. https://doi.org/10.5358/hsj.34.128

Eto K, Matsui M, Nishikawa K (2016) A new highland species of dwarf litter frog genus Leptobrachella (Amphibia: Anura: Megophryidae) from Sarawak. Raffles Bulletin of Zoology 64: 194-203.

Eto K, Matsui M, Hamidy A, Munir M, Iskandar D (2018) Two New Species of the Genus Leptobrachella (Amphibia: Anura: Megophryidae) from Kalimantan, Indonesia. Current Herpetology 37(2): 95-105. https://doi.org/10.5358/hsj.37.95

Fei L, Ye CY, HuangYZ (1990) Key to Chinese Amphibians. Publishing House for Scientific and Technological Literature, Chongqing, 364 pp. [in Chinese]

Fei L, Ye CY (1992) The classification of Pelobatidae (Leptolalax) and a new species in China. Acta Zoologica Sinica 38(3): 245-253. [in Chinese]

Fei L, Ye CY (2005) An Illustrated Key to Chinese Amphibians. Sichuan Publishing House of Science and Technology, Chongqing, 340 pp. [in Chinese]

Fouquet A, Gilles A, Vences M, Marty C, Blanc M, Gemmell1 NJ (2007) Underestimation of species richness in Neotropical frogs revealed by mtDNA analyses. PLoS ONE 2(10): e1109. https://doi.org/10.1371/journal.pone.0001109

Fei L, Hu SQ, Ye CY, Huang YZ (2009) Fauna Sinica. Amphibia, Vol. 2, Anura. Science Press, Beijing, 957 pp. [in Chinese]

Fei L, Ye CY, Jiang JP (2012) Colored Atlas of Chinese Amphibians and yheir Distributions. Sichuan Science and Technology Press, Sichuan, 619 pp. [in Chinese]

Frost DR (2019) Amphibian Species of the World: an Online Reference. Version 6.0. Electronic Database. American Museum of Natural History, New York. http://research.amnh.org/herpetology/amphibia/index.html [Accessed on: 2019-8-13]

Günther A (1872) On the reptiles and amphibians of Borneo. Proceedings of the Zoological Society of London 1872: 586-600.

Günther A (1895) The reptiles and batrachians of the Natuna Islands. Novitates Zoologicae 2(4): 499-502.

Grismer LL, Grismer JL, Youmans TM (2004) A new species of Leptolalax (Anura: Megophryidae) from Pulau Tioman, West Malaysia. Asiatic Herpetological Research 10: 8-11.

Hu SQ, Zhao EM, Liu CC (1973) A survey of amphibians and reptiles in Kweichow province, including a herpetofaunal analysis. Acta Zoologica Sinica 19: 149-181.

Humtsoe LN, Bordoloi S, Ohler A, Dubois A (2008) Rediscovery of a long known species, Ixalus lateralis Anderson, 1871. Zootaxa 1921: 24-34. https://doi.org/10.11646/ zootaxa.1921.1.2

Hoang DT, Chernomor O, von Haeseler A, Minh BQ, Vinh L (2018) UFBoot2: improving the ultrafast bootstrap approximation. Molecular Biology and Evolution 35(2): 518-522. https://doi.org/10.1093/molbev/msx281

Hou Y, Zhang MF, Hu F, Li SY, Shi SC, Chen J, Mo XY, Wang B (2018) A new species of the genus Leptolalax (Anura, Megophryidae) from Hunan, China. Zootaxa 4444(3): 247-266. https://doi.org/10.11646/zootaxa.4444.3.2

Inger RF, Stuebing RB (1992) A new species of frog of the genus Leptobrachella Smith (Anura: Pelobatidae), with a key to the species from Borneo. Raffles Bulletin of Zoology 39(1): 99-103. 
Inger RF, Stuebing RB, Tan F (1995) New species and new records of anurans from Borneo. Raffles Bulletin of Zoology 43: 115-132.

Inger RF (1997) A new species of Leptolalax (Anura: Megophryidae) from Borneo. Asiatic Herpetological Research 7: 48-50. https://doi.org/10.5962/bhl.part.18855

Inger RF, Orlov N, Darevsky I (1999) Frogs of Vietnam: a report on new collections. Fieldiana, Zoology 92: 1-46. https://doi.org/10.5962/bhl.title.3478

Jiang K, Yan F, Suwannapoom C, Chomdej S, Che J (2013) A new species of the genus Leptolalax (Anura: Megophryidae) from northern Thailand. Asian Herpetological Research 4(2): 100-108. https://doi.org/10.3724/SP.J.1245.2013.00100

Kumar S, Stecher G, Tamura K (2016) MEGA7: Molecular Evolutionary Genetics Analysis Version 7.0 for Bigger Datasets. Molecular Biology and Evolution 33(7): 1870-1874. https://doi.org/10.1093/molbev/msw054

Liu CC (1950) Amphibians of Western China. Fieldiana, America Zoology Memoires 2: 1-400. https://doi.org/10.5962/bhl.title.2977

Lathrop A, Murphy RW, Orlov N, Ho CT (1998) Two new species of Leptolalax (Anura: Megophryidae) from northern Vietnam. Amphibia-Reptilia 19: 253-267. https://doi. org/10.1163/156853898X00160

Lanfear R, Frandsen PB, Wright AM, Senfeld T, Calcott B (2016) PartitionFinder 2: new methods for selecting partitioned models of evolution for molecular and morphological phylogenetic analyses. Molecular Biology and Evolution 34(3): 772-773. https://doi. org/10.1093/molbev/msw260

Malkmus R (1992) Leptolalax pictus sp. n. (Anura: Pelobatidae) vom Mount Kinabalu/NordBorneo. Sauria 14: 3-6.

Matsui M (1997) Call characteristics of Malaysian Leptolalax with a description of two new species (Anura: Pelobatidae) Copeia 1997: 158-165. https://doi.org/10.2307/1447851

Matsui M (2006) Three new species of Leptolalax from Thailand (Amphibia, Anura, Megophryidae). Zoological Science 23(9): 821-830. https://doi.org/10.2108/zsj.23.821

Matsui M, Belabut DM, Ahmad N, Yong HS (2009) A new species of Leptolalax (Amphibia, Anura, Megophryidae) from peninsular Malaysia. Zoological Science 26(3): 243-247. https://doi.org/10.2108/zsj.26.243

Mathew R, Sen N (2010) Description of a new species of Leptobrachium Tschudi, 1838 (Amphibia: Anura: Megophryidae) from Meghalaya, India. Records of the Zoological Survey of India 109: 91-108.

Matsui M, Dehling J M (2012) Notes on an enigmatic Bornean megophryid, Leptolalax dringi Dubois, 1987 (Amphibia: Anura). Zootaxa 3317(1): 49-58. https://doi.org/10.11646/ zootaxa.3317.1.4

Matsui M, Zainudin R, Nishikawa K (2014a) A new species of Leptolalax from Sarawak, western Borneo (Anura: Megophryidae). Zoological Science 31(11): 773-779. https://doi. org/10.2108/zs140137

Matsui M, Nishikawa K, Yambun P (2014b) A new Leptolalax from the mountains of Sabah, Borneo (Amphibia, Anura, Megophryidae). Zootaxa 3753(3): 440-452. https://doi. org/10.11646/zootaxa.3753.5.3

Mahony S, Foley NM, Bijumn SD, Teeling EC (2017) Evolutionary history of the Asian horned frogs (Megophryinae): integrative approaches to timetree dating in the absence of a 
fossil record. Molecular Biology and Evolution 34(3): 744-771. https://doi.org/10.1093/ $\mathrm{molbev} / \mathrm{msw} 267$

Matsui M, Eto K, Nishikawa K, Hamidy A, Belabut D, Ahmad N, Panha S, Khonsue W, Grismer LL (2017) Mitochondrial phylogeny of Leptolalax from Malay Peninsula and Leptobrachella (Anura, Megophryidae). Current Herpetology 36(1): 11-21. https://doi. org/10.5358/hsj.36.11

Murphy RW, Lathrop A, Ho CT, Orlov N (1998) Two new species of Leptolalax (Anura: Megophryidae) from northern Vietnam. Amphibia-Reptilia 19(3): 253-267. https://doi. org/10.1163/156853898X00160

Nguyen LT, Schmidt HA, Haeseler, A von, Minh BQ (2015) IQ-TREE: a fast and effective stochastic algorithm for estimating maximum-likelihood phylogenies. Molecular Biology and Evolution 32(1): 268-274. https://doi.org/10.1093/molbev/msu300

Nguyen LT, Poyarkov Jr NA, Le DT, Vo BD, Phan HT, Van DT, Murphy WR, Nguyen SN (2018) A new species of Leptolalax (Anura: Megophryidae) from Son Tra Peninsula, central Vietnam. Zootaxa 4388(1): 1-21. https://doi.org/10.11646/zootaxa.4388.1.1

Ohler A, Marquis O, Swan S, Grosjean S (2000) Amphibian biodiversity of Hoang Lien Nature Reserve (Lao Cai Province, northern Vietnam) with description of two new species. Herpetozoa 13 (1/2): 71-87.

Ohler A, Wollenberg KC, Grosjean S, Hendrix R, Vences M, Ziegler T, Dubois A (2011) Sorting out Lalos: description of new species and additional taxonomic data on megophryid frogs from northern Indochina (genus Leptolalax, Megophryidae, Anura). Zootaxa 3147: 1-83. https://doi.org/10.11646/zootaxa.3147.1.1

Oberhummer E, Barten C, Schweizer IN, Das I, Haas AL, Hertwig ST (2014) Description of the tadpoles of three rare species of megophryid frogs (Amphibia: Anura: Megophryidae) from Gunung Mulu, Sarawak, Malaysia. Zootaxa 3835: 59-79. https://doi.org/10.11646/ zootaxa.3835.1.3

Poyarkov NA, Rowley JJ, Gogoleva SI, Vassilieva AB, Galoyan EA, Orlov N L (2015) A new species of Leptolalax (Anura: Megophryidae) from the western Langbian Plateau, southern Vietnam. Zootaxa 3931: 221-252. https://doi.org/10.11646/zootaxa.3931.2.3

Rowley JJ, Cao TT (2009) A new species of Leptolalax (Anura: Megophryidae) from central Vietnam. Zootaxa 2198 (5): 51-60. https://doi.org/10.11646/zootaxa.2198.1.5

Rowley JJ, Hoang DH, Le TTD, Dau QV, Cao TT (2010a) A new species of Leptolalax (Anura: Megophryidae) from Vietnam and further information on Leptolalax tuberosus. Zootaxa 2660: 33-45.

Rowley JJ, Stuart BL, Neang T, Emmett DA (2010b) A new species of Leptolalax (Anura: Megophryidae) from northeastern Cambodia. Zootaxa 2567: 57-68. https://doi. org/10.11646/zootaxa.2567.1.3

Rowley JJ, Stuart BL, Richards SJ, Phimmachak S, Sivongxay N (2010c) A new species of Leptolalax (Anura: Megophryidae) from Laos. Zootaxa 2681: 35-46. https://doi.org/10.11646/ zootaxa.2681.1.3

Rowley JJ, Le DTT, Tran DTA, Hoang DH (2011) A new species of Leptobrachella (Anura: Megophryidae) from southern Vietnam. Zootaxa 2796: 15-28. https://doi.org/10.11646/ zootaxa.2796.1.2 
Rowley JJ, Hoang HD, Dau VQ, Le TTD, Cao TT (2012) A new species of Leptolalax (Anura: Megophryidae) from central Vietnam. Zootaxa 3321: 56-68. https://doi.org/10.11646/ zootaxa.3321.1.4

Ronquist F, Teslenko M, Van Der Mark P, Ayres DL, Darling A, Höhna S, Larget B, Liu L,Suchard MA, Huelsenbeck JP (2012) MrBayes 3.2: efficient Bayesian phylogenetic inference and model choicem across a large model space. Systematic Biology 61: 539-542. https://doi.org/10.1093/sysbio/sys029

Rowley JJ, Dau VQ, Nguyen TT (2013) A new species of Leptolalax (Anura: Megophryidae) from the highest mountain in Indochina. Zootaxa 3737 (4): 415-428. https://doi. org/10.11646/zootaxa.3737.4.5

Rambaut A, Suchard MA, Xie D, Drummond AJ (2014) Tracer v1. 6. http://beast.bio.ed.ac. uk/Tracer [Accessed on: 2019-3-7]

Rowley JJ, Stuart BL, Neang T, Hoang HD, Dau VQ, Nguyen TT, Emmett DA (2015a) A new species of Leptolalax (Anura: Megophryidae) from Vietnam and Cambodia. Zootaxa 4039: 401-417. https://doi.org/10.11646/zootaxa.4039.3.1

Rowley JJL, Tran DTA, Frankham GJ, Dekker AH, Le DTT, Nguyen TQ, Dau VQ, Hoang HD (2015b) Undiagnosed Cryptic Diversity in Small, Microendemic Frogs (Leptolalax) from the Central Highlands of Vietnam. PLoS ONE 10 (5): e0128382. https://doi. org/10.1371/journal.pone.0128382

Rowley JJ, Tran DTA, Le DTT, Dau VQ, Peloso PLV, Nguyen TQ, Hoang HD, Nguyen TT, Ziegler T (2016) Five new, microendemic Asian Leaf-litter Frogs (Leptolalax) from the southern Annamite mountains, Vietnam. Zootaxa 4085: 63-102. https://doi. org/10.11646/zootaxa.4085.1.3

Rowley JJ, Dau VQ, Hoang HD, Le DTT, Cutajar TP, Nguyen TT (2017a) A new species of Leptolalax (Anura: Megophryidae) from northern Vietnam. Zootaxa 4243: 544-564. https://doi.org/10.11646/zootaxa.4243.3.7

Rowley J J, Dau V Q, Cao T T (2017b) A new species of Leptolalax (Anura: Megophryidae) from Vietnam. Zootaxa 4273(1): 61-79. https://doi.org/10.11646/zootaxa.4273.1.5

Smith MA (1925) Contributions to the herpetology of Borneo. Sarawak Museum Journal 3: 15-34.

Stejneger L(1926) Two new tailless amphibians from western China. Proceedings of the Biological Society of Washington 39: 53-54.

Smith MA (1931) The herpetology of Mt. Kinabalu, North Borneo, 13,455 ft. Bulletin of the Raffles Museum. Singapore 5: 3-32.

Simon C, Frati F, Beckenbach A, Crespi B, Liu H, Flook P (1994) Evolution, weighting, and phylogenetic utility of mitochondrial gene sequences and a compilation of conserved polymerase chain reaction primers. Annals of the Entomological Society of America 87: 651-701. https://doi.org/10.1093/aesa/87.6.651

Sengupta S, Sailo S, Lalremsanga HT, Das A, Das I (2010) A new species of Leptolalax (Anura: Megophryidae) from Mizoram, north-eastern India. Zootaxa 2406: 56-68. https://doi. org/10.11646/zootaxa.2406.1.3

Sung YH, Yang JH, Wang YY (2014) A new species of Leptolalax (Anura: Megophryidae) from southern China. Asian Herpetological Research 5(2): 80-90. https://doi.org/10.3724/ SP.J.1245.2014.00080 
Taylor EH (1962) The amphibian fauna of Thailand. University of Kansas Science Bulletin 43: 265-599. https://doi.org/10.5962/bhl.part.13347

Watters JL, Cummings ST, Flanagan RL, Siler CD (2016) Review of morphometric measurements used in anuran species descriptions and recommendations for a standardized approach. Zootaxa 4072(4): 477-495. https://doi.org/10.11646/zootaxa.4072.4.6

Wang J, Yang JH, Li, Y, Lyu ZT, Zeng ZC, Liu ZY, Ye YH, Wang YY (2018) Morphology and molecular genetics reveal two new Leptobrachella species in southern China (Anura, Megophryidae). ZooKeys 776: 105-106. https://doi.org/10.3897/zookeys.776.22925

Wang J, Li YL, Li Y, Chen HH, Zeng YJ, Shen JM, Wang YY (2019) Morphology, molecular genetics, and acoustics reveal two new species of the genus Leptobrachella from northwestern Guizhou Province, China (Anura, Megophryidae). ZooKeys 848: 119-154. https:// doi.org/10.3897/zookeys.848.29181

Yang JH, Wang YY, Chen GL, Rao DQ (2016) A new species of the genus Leptolalax (Anura: Megophryidae) from Mt. Gaoligongshan of western Yunnan Province, China. Zootaxa 4088: 379-394. https://doi.org/10.11646/zootaxa.4088.3.4

Yuan ZY, Sun RD, Chen J, Rowley JJ, Wu ZJ, Hou SB, Wang SN, Che J (2017) A new species of the genus Leptolalax (Anura: Megophryidae) from Guangxi, China. Zootaxa 4300(4): 551-570. https://doi.org/10.11646/zootaxa.4300.4.5

Yang JH, Zeng ZC, Wang YY (2018) Description of two new sympatric species of the genus Leptolalax (Anura: Megophryidae) from western Yunnan of China. PeerJ 6: e4586. https:// doi.org/10.7717/PeerJ.458 